\title{
Silicon carbide filters and porous membranes: A review of processing, properties, performance and application
}

\author{
Dachamir Hotza ${ }^{a, *}$, Marco Di Luccio ${ }^{a}$, Michaela Wilhelm ${ }^{\text {b }}$, Yuji Iwamoto ${ }^{c}$, Samuel Bernard ${ }^{d}$, \\ João C. Diniz da Costa ${ }^{e, f, * *}$ \\ a Department of Chemical Engineering and Food Engineering (EQA), Federal University of Santa Catarina (UFSC), 88040-900, Florian polis, Brazil \\ ${ }^{\mathrm{b}}$ Institute of Advanced Ceramics, University of Bremen, D-28359, Bremen, Germany \\ ${ }^{\mathrm{c}}$ Department of Life Science and Applied Chemistry, Nagoya Institute of Technology, Gokiso-cho, Showa-ku, Nagoya, Aichi, 466-8555, Japan \\ ${ }^{\mathrm{d}}$ University of Limoges, CNRS, IRCER, UMR 7315, F-87000, Limoges, France \\ ${ }^{\mathrm{e}}$ The University of Queensland, FIM Lab - Films and Interfacial Materials Membranes Laboratory, School of Chemical Engineering, Brisbane, OLD 4072, Australia \\ ${ }_{\mathrm{f}}$ REQUIMTE/LAQV, (Bio)Chemical Process Engineering, Department of Chemistry, Faculty of Science and Technology, Universidade Nova de Lisboa, 2829-516, \\ Caparica, Portugal
}

\section{ARTICLEINFO}

\section{Keywords:}

Silicon carbide

Filters and membranes

Ceramic processing

Properties

Separation applications

\begin{abstract}
A B STRACT
Silicon carbide $(\mathrm{SiC})$ filters and porous membranes is a growing industry with deployment for gas and liquid separation processes. In view of its importance, the research efforts into the development of SiC filters and membranes are of growing interest around the world. Therefore, this review paper is focused on the latest advancements in $\mathrm{SiC}$ and $\mathrm{SiC}$ composites used for the preparation of substrates and thin films in filters and membranes. There is a multitude of methods used to prepare filters and membranes of different shapes (tubular, honeycomb, flat sheets and multi-channel), which are influenced by precursor mixture and sintering conditions. In turn, these processing conditions affect porosity and pore size, which affects the transport and separation properties of $\mathrm{SiC}$ filters and membranes. $\mathrm{SiC}$ particles size and distribution allow for the precise control of pore size in membranes, leading to high gas separation factors. In addition, SiC has strong thermal stability properties that are very desirable for high temperature gas cleaning. Together with gas and liquid transport and separation properties, this review also addresses the potential applications in gas and liquid separation processes, coupled with thermal/chemical stability properties. Future challenges are highlighted towards further research efforts.
\end{abstract}

\section{Introduction}

Silicon carbide $(\mathrm{SiC})$ production started more than a century ago by heating a mixture of quartz sand as silica $\left(\mathrm{SiO}_{2}\right)$ and powdered coke (carbon) in an iron bowl according to the Acheson process [1]. Since then, other synthesis methods have been developed for the production of $\mathrm{SiC}$ nanostructures [2] or macroporous monoliths [3,4]. Furthermore, different processing routes for porous $\mathrm{SiC}$ ceramics have been applied to satisfy the associated requirements of porosity, pore size and degree of interconnectivity [5,6]. Porous $\mathrm{SiC}$ ceramics can be also produced by adding organic templates [7], sacrificial pore formers [8], direct foaming [9] or reaction sintering [10]. These methods require high temperatures $\left(500^{\circ} \mathrm{C}\right)$ if $\mathrm{SiC}$ powder is used as a starting material [4, $11]$.

$\mathrm{SiC}$ has been making inroads into filters and porous ceramic membranes applications. Indeed this market segment is mainly dominated by oxide-based porous materials such as alumina $\left(\mathrm{Al}_{2} \mathrm{O}_{3}\right)$ [12], zirconia $\left(\mathrm{ZrO}_{2}\right)$ [13], titania $\left(\mathrm{TiO}_{2}\right)$ [14] and silica $\left(\mathrm{SiO}_{2}\right)$ [15]. SiC filters and porous membranes have unique characteristics when compared to their oxide counterparts, including high temperature resistance and, in some applications, improved chemical stability. Therefore, SiC filters and membranes are becoming integral part of separation of gas and liquid in processing industries such as wastewater, energy, gas cleaning, gas separation, food and pharmaceutical. Filters stop the passage of particles

\footnotetext{
* Corresponding author. Department of Chemical Engineering and Food Engineering (EQA), Federal University of Santa Catarina (UFSC), 88040-900, Florianopolis SC, Brazil.

** Corresponding author. The University of Queensland, FIM²Lab - Films and Interfacial Materials Membranes Laboratory, School of Chemical Engineering,

Brisbane, QLD 4072, Australia.

E-mail addresses: d.hotza@ufsc.br (D. Hotza), j.dacosta@uq.edu.au (J.C. Diniz da Costa).
} 
whilst allowing gases to get through; porous inorganic membranes have been used to separate gases or liquids by a mechanism known as molecular size exclusion.

The scope of this review paper is on SiC filters and porous membranes. It starts with a summary of materials and processes used to prepare $\mathrm{SiC}$ and $\mathrm{SiC}$ composite substrates, including sintering and structural aspects related to pore structure and mechanical properties. The substrates are mainly used as filters whilst the same substrates are also used for the preparation of membranes. Hence, the main processes for coating SiC thin-film top layers are also addressed. Subsequently, this review paper focuses on transport phenomena associated with gas and liquid transport in $\mathrm{SiC}$ filters and membranes. The discussion considers gas transport versus structural properties in filters, and Robeson plots in membranes for a few important gas separation processes. Thermal and chemical stability is also addressed in view of the importance of the industrial deployment of SiC filters and membranes. This review paper progresses towards separation process applications and potential challenges. Of particular attention, the industrial production of $\mathrm{SiC}$ filter and membranes in different shapes (i.e. tubes, flat sheets, multi-channel and honeycomb) is discussed. Overall, this review paper is focused on the latest advancements in the production, structural properties, challenges and industrial uptake of $\mathrm{SiC}$ filters and porous membranes.

\section{Processing SiC filters and membranes}

The majority of the SiC filters and porous membranes reported in the open literature or commercially available are composed of coarse porous substrates (also known as supports) as depicted in Fig. 1, which can be either $\mathrm{SiC}$ or $\mathrm{SiC}$ composite ceramics. These porous substrates can be used directly as filters or for the deposition of top layers (as thin films) in membranes for separation processes. The porous substrate therefore provides the bulk mechanical strength for industrial application whilst the coating of top layers in membranes provides the required industrial properties for processing liquids and gases.

\subsection{Substrates}

The fabrication processing steps of porous substrates include raw

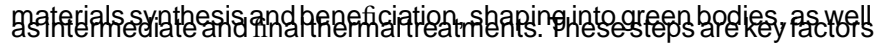

for developing structure and properties. Table 1 lists a summary of relevant information of $\mathrm{SiC}$ substrates reported in the literature. There are a variety of fabrication processes, shapes of substrates, heat treatments and an array of starting powers, polymer precursors, and additives used for the preparation of $\mathrm{SiC}$ or $\mathrm{SiC}$ composite substrates.
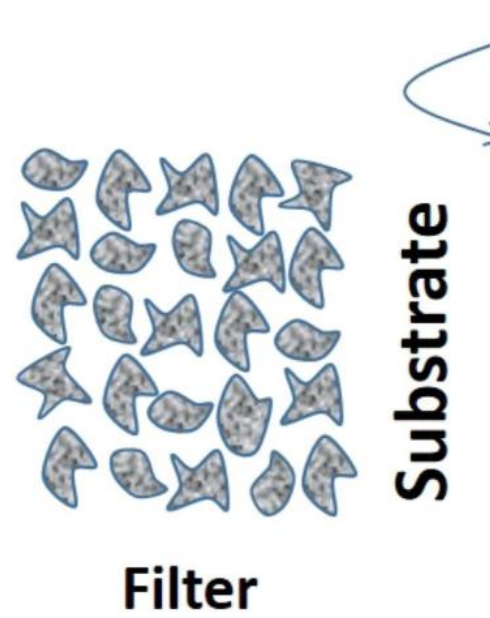

$$
\text { Top-Layer }
$$

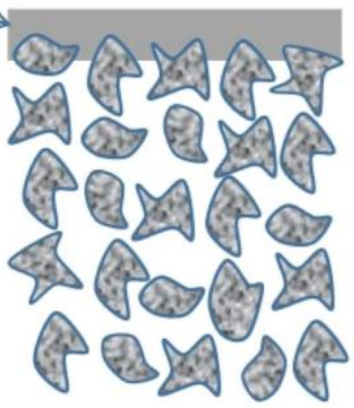

Membrane
Table 1

Processing parameters of $\mathrm{SiC}$ and $\mathrm{SiC}$ composite substrates.

\begin{tabular}{|c|c|c|c|c|}
\hline $\begin{array}{l}\text { Starting powders, } \\
\text { polymer precursors and } \\
\text { additives (mean particle } \\
\text { size in } \mu \mathrm{m} \text { ) }\end{array}$ & $\begin{array}{l}\text { Shaping } \\
\text { process }\end{array}$ & $\begin{array}{l}\text { Shape and } \\
\text { size }(\mathrm{mm})\end{array}$ & $\begin{array}{l}\text { Thermal } \\
\text { treatments }\end{array}$ & Ref. \\
\hline $\begin{array}{l}\alpha-\operatorname{SiC}(1.0), \beta-S i C \\
(0.03-0.6), \mathrm{B}_{4} \mathrm{C}^{\mathrm{a}}, \\
\text { Phenolic resin }{ }^{\mathrm{a}}, \\
\text { Carbon black }^{\mathrm{a}}, \mathrm{Al} \mathrm{O}_{3}{ }^{\mathrm{a}}, \\
\text { Oleic acid }^{\mathrm{e}}\end{array}$ & $\begin{array}{l}\text { Uniaxial } \\
\text { pressing } \\
\mathrm{MPa}_{117}^{117}\end{array}$ & Disks (32 Ø) & $\begin{array}{l}19500^{\circ} \mathrm{C} \text { in } \\
\mathrm{Ar}\end{array}$ & [16] \\
\hline$\beta-\operatorname{SiC}(0.6)$ & $\begin{array}{l}\text { Uniaxial } \\
\text { pressing }\end{array}$ & Disks & $\begin{array}{l}1950^{\circ} \mathrm{C} \text { in } \\
\mathrm{Ar}\end{array}$ & {$[17]$} \\
\hline$\beta-\operatorname{SiC}(0.6)$ & $\begin{array}{l}\text { Uniaxial } \\
\text { pressing }\end{array}$ & $\begin{array}{l}\text { Tubes }(12 \\
\text { outer } \emptyset, 3 \\
\text { thick, } 40 \\
\text { long) }\end{array}$ & $\begin{array}{l}1800{ }^{\circledR} \mathrm{C} / 3 \mathrm{~h} \\
\text { in } \mathrm{He}\end{array}$ & [18] \\
\hline$\beta-\operatorname{SiC}(0.6)$ & $\begin{array}{l}\text { Uniaxial } \\
\text { pressing }\end{array}$ & $\begin{array}{l}\text { Tubes }(12 \\
\text { outer } \emptyset, 3 \\
\text { thick, } 40 \\
\text { long) }\end{array}$ & $\begin{array}{l}1700^{\circledR} \mathrm{C} / 3 \mathrm{~h} \\
\text { in } \mathrm{He}\end{array}$ & [19] \\
\hline$\underset{\text { Graphite }^{\alpha}}{\alpha-S i C, \alpha-A t @}$ & $\begin{array}{l}\text { Uniaxial } \\
\text { pressing, } \\
\text { machining }\end{array}$ & $\begin{array}{l}\text { Disks }(20 \varnothing \\
-3)\end{array}$ & $\begin{array}{l}1350-1500 \\
{ }^{\circ} \mathrm{C} / 4 \mathrm{~h} \text { in air }\end{array}$ & [20] \\
\hline $\begin{array}{l}\text { B-SiC (0.3), } \alpha-\mathrm{Al}_{2} \mathrm{O}_{3} \\
\quad(0.2)^{\mathrm{a}}\end{array}$ & $\begin{array}{l}\text { Uniaxial } \\
\text { pressing } \\
@ \text { @ } 40 \mathrm{MPa} ; \\
\text { Cold } \\
\text { Isostatic } \\
\text { Pressing } \\
\text { (CIP) @ } \\
100 \text { or } \\
400 \mathrm{MPa}\end{array}$ & $\begin{array}{l}\text { Disks }(20 \varnothing \\
\bigotimes 5)\end{array}$ & $\begin{array}{l}1500-1800 \\
{ }^{\circ} \mathrm{C} / 2 \mathrm{~h} \text { in } \mathrm{Ar}\end{array}$ & [21-23] \\
\hline $\begin{array}{l}\alpha-\mathrm{SiC}(0.45), \beta-\mathrm{SiC}(1.7) \\
\mathrm{Al}_{2} \mathrm{O}_{3}{ }^{\mathrm{a}}, \mathrm{Y}_{3}^{\mathrm{a}} \text {, } \\
\text { Polyethylene glycol } \\
(\mathrm{PEG})^{\mathrm{b}}, \text { Poly } \\
\text { (methylmethacrylate) } \\
\text { (PMMA) }\end{array}$ & $\begin{array}{l}\text { Uniaxial } \\
\text { pressing } \\
@ 50 \mathrm{MPa}\end{array}$ & $\begin{array}{l}\text { Bars }(30 \\
25\end{array}$ & $\begin{array}{l}1000^{\star} \mathrm{C} / 4 \\
\mathrm{~h}, 1950^{\star} \mathrm{C} / \\
4 \mathrm{~h} \text { in } \mathrm{Ar}\end{array}$ & [24] \\
\hline $\begin{array}{l}\alpha \text {-SiC (22), Polyvinyl } \\
\text { alcohol (PVA) } \\
\text { Petroleum coke }(11)^{f}\end{array}$ & $\begin{array}{l}\text { Uniaxial } \\
\text { pressing } \\
@ 23 \mathrm{MPa}\end{array}$ & $\begin{array}{l}\text { Bars }(50 \\
20 \diamond 16) \text { and } \\
\text { disks }(40 \varnothing \\
10)\end{array}$ & $\begin{array}{l}1100 \& \\
1300^{\circ} \mathrm{C} / 4 \mathrm{~h} \\
\text { in air }\end{array}$ & [25] \\
\hline $\begin{array}{c}\alpha-\operatorname{SiC}(22), \alpha-\mathrm{Al}_{2} \mathrm{O}_{3}(6)^{\mathrm{a}}, \\
\mathrm{MgO}(4)^{\mathrm{a}}, \text { Petroleum } \\
\text { coke }(11)^{\dagger}, \mathrm{PVA}^{\mathrm{b}}\end{array}$ & $\begin{array}{l}\text { Uniaxial } \\
\text { pressing } \\
@ 23 \mathrm{MPa}\end{array}$ & $\begin{array}{l}\text { Bars }(47 \bullet \\
20 \diamond 13) \text { and } \\
\text { disks }(40 \varnothing\end{array}$ & $\begin{array}{l}1100^{\otimes} \mathrm{C} / 4 \\
\mathrm{~h}, 1350^{\star} \mathrm{C} / \\
4 \mathrm{~h}\end{array}$ & [26] \\
\hline$\alpha-\operatorname{SiC}(22), \alpha-\operatorname{Al} O_{23}^{(6)^{a}}$ & Uniaxial & $\begin{array}{l}\text { 10) } \\
\text { Bars (50 }\end{array}$ & $11000^{\otimes} \mathrm{C} / 4$ & [27] \\
\hline $\begin{array}{l}\text { Petroleum coke (11), } \\
\text { PVA }^{\text {b }}\end{array}$ & $\begin{array}{l}\text { pressing } \\
@ 23 \mathrm{MPa}\end{array}$ & $\begin{array}{l}2016) \text { and } \\
\text { disks }(40 \varnothing\end{array}$ & $\begin{array}{l}\mathrm{h}, 1500^{\star} \mathrm{C} / \\
4 \mathrm{~h}\end{array}$ & \\
\hline$\beta-\operatorname{SiC}(0.6), \beta-S i C$ & Uniaxial & $\begin{array}{l}\text { 10) } \\
\text { Tubes }\end{array}$ & $4500^{\otimes} / 2 \mathrm{~h}$ & [28] \\
\hline $\begin{array}{l}\text { (0.1-0.2), SiC } \\
\text { nanofibers }\end{array}$ & pressing & & in air; 1700 & \\
\hline $\mathrm{SiC}$ & $\begin{array}{l}\text { Uniaxial } \\
\text { pressing }\end{array}$ & $\begin{array}{l}\text { Disks }(25 \varnothing \\
\diamond 5)\end{array}$ & & [29] \\
\hline 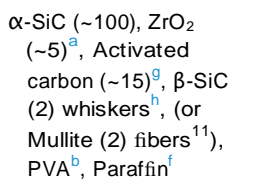 & $\begin{array}{l}\text { Uniaxial } \\
\text { pressing } \\
@ 8 \mathrm{MPa}\end{array}$ & $\begin{array}{l}\text { Disks ( } 30 \varnothing \\
-3) \text { and } \\
\text { strips }(50 \bullet \\
6 \bullet 6)\end{array}$ & $\begin{array}{l}1450-1550 \\
\text { air } / 2-6 \mathrm{~h} \text { in } \\
\text { air }\end{array}$ & {$[30,31]$} \\
\hline $\begin{array}{l}\alpha-\mathrm{SiC}(98 \text { or } 300), \mathrm{CaO} \\
(\sim 5)^{\mathrm{a}}, \mathrm{ZrO}_{2}(\sim 5)^{\mathrm{a}}, \\
\text { Activated carbon }^{\dagger} \\
(\sim 20)^{\dagger}, \text { Mullite }(2) \\
\text { fibers }^{\mathrm{h}}, \mathrm{PVA}^{\mathrm{b}}, \text { Paraffin }^{\dagger}\end{array}$ & $\begin{array}{l}\text { Uniaxial } \\
\text { pressing } \\
@ 8 \mathrm{MPa}\end{array}$ & $\begin{array}{l}\text { Disks ( } 30 \varnothing \\
\text { 3) and } \\
\text { strips }(50 \\
6 \bullet 6)\end{array}$ & $\begin{array}{l}1550 \mathrm{C} / \\
2-6 \mathrm{~h} \text { in air, } \\
\text { or } 500 \mathrm{C} / 2 \\
\mathrm{~h} \text { and } 1450 \\
\mathrm{C} / 4 \mathrm{~h} \text { in air }\end{array}$ & {$[32,33]$} \\
\hline 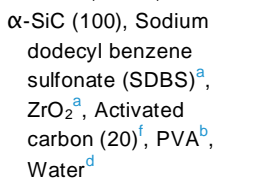 & $\begin{array}{l}\text { Uniaxial } \\
\text { pressing } \\
@ 8 \mathrm{MPa}\end{array}$ & $\begin{array}{l}\text { Disks ( } 30 \varnothing \\
-3) \text { and } \\
\text { strips }(50 \diamond \\
6 \diamond 6)\end{array}$ & $\begin{array}{l}1150^{\star} \mathrm{C} / 4 \mathrm{~h} \\
\text { in air }\end{array}$ & [34] \\
\hline SiC (5-125), Glass frit ${ }^{\mathrm{a}}$ & $\begin{array}{l}\text { Uniaxial } \\
\text { pressing } \\
@ 30 \mathrm{MPa}\end{array}$ & $\begin{array}{l}\text { Disks }(20 \text { or } \\
50 \varnothing \bullet 10)\end{array}$ & $850^{\circ} \mathrm{C} / 1 \mathrm{~h}$ & [35] \\
\hline
\end{tabular}

(continued on next page)

Fig. 1.Idealized schematic of porous substrates and membranes showing a top layer. 
Table 1 (continued)

\begin{tabular}{|c|c|c|c|c|}
\hline $\begin{array}{l}\text { Starting powders, } \\
\text { polymer precursors and } \\
\text { additives (mean particle } \\
\text { size in } \mu \mathrm{m} \text { ) }\end{array}$ & $\begin{array}{l}\text { Shaping } \\
\text { process }\end{array}$ & $\begin{array}{l}\text { Shape and } \\
\text { size }(\mathrm{mm})\end{array}$ & $\begin{array}{l}\text { Thermal } \\
\text { treatments }\end{array}$ & Ref. \\
\hline $\begin{array}{l}\text { SiC }(10-65), \text { Glass frit }{ }^{\mathrm{a}} \\
\text { Polyethylene glycol } \\
(\mathrm{PEG})^{\mathrm{b}},(\mathrm{PVA})^{\mathrm{b}}\end{array}$ & $\begin{array}{l}\text { Uniaxial } \\
\text { pressing } \\
@ 40 \mathrm{MPa}\end{array}$ & $\begin{array}{l}\text { Disks }(25 \varnothing \\
-3.5)\end{array}$ & $\begin{array}{l}850^{\circledR} \mathrm{C} / 2 \mathrm{~h} \\
\text { in air }\end{array}$ & \\
\hline 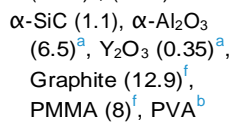 & $\begin{array}{l}\text { Uniaxial } \\
\text { pressing } \\
@ 23 \mathrm{MPa}\end{array}$ & $\begin{array}{l}\text { Disks }(40 \varnothing) \\
\text { and bars }(50 \\
20-16)\end{array}$ & $\begin{array}{l}850 \mathrm{C} / 2 \mathrm{~h} \\
\text { in air; } 1300 \\
{ }^{\circ} \mathrm{C} / 2 \mathrm{~h} \text { in air } \\
\text { or } 1700 \mathrm{C} /\end{array}$ & [37] \\
\hline $\begin{array}{l}\text { SiC }(120), B C(1)^{a} \\
\text { PVA }^{b}\end{array}$ & $\begin{array}{l}\text { Uniaxial } \\
\text { pressing } \\
@ 30 \mathrm{MPa}\end{array}$ & $\begin{array}{l}\text { Bars }(658 \\
\diamond 8) \text { and } \\
\text { disks (30Ø } \\
\diamond 5)\end{array}$ & $\begin{array}{l}2 \mathrm{~h} \text { in } \mathrm{Ar} \\
2100-2250 \\
\mathrm{C} / 1 \mathrm{~h}\end{array}$ & {$[38,39]$} \\
\hline $\begin{array}{c}\alpha-\operatorname{SiC}(1,20), \alpha-\mathrm{Al}_{2} \mathrm{O}_{3} \\
(1.5)^{\mathrm{a}}, \mathrm{Y}_{2} \mathrm{O}_{3}(0.8)^{\mathrm{a}}\end{array}$ & $\begin{array}{l}\text { Hot } \\
\text { pressing } \\
@ 1800 \\
\mathrm{C} / 30 \\
\mathrm{MPa}\end{array}$ & & $\begin{array}{l}1800{ }^{\circ} \mathrm{C} / 2 \mathrm{~h} \\
@ 30 \mathrm{MPa}\end{array}$ & [40] \\
\hline $\begin{array}{l}\alpha-\operatorname{SiC}(0.30), \mathrm{Al}_{2} \mathrm{O}_{3} \\
(0.17)^{\mathrm{a}}, \text { Cellulose }^{\mathrm{b}}, \\
\text { Water }^{\mathrm{d}}\end{array}$ & Extrusion & $\begin{array}{l}\text { Tubes }(6 \\
\emptyset_{\text {ext }}, 2 \text { thick, } \\
100-600 \\
\text { long) }\end{array}$ & $\begin{array}{l}6000^{\star} \mathrm{C} / 2 \mathrm{~h}, \\
18000^{\star} \mathrm{C} / 2 \mathrm{~h} \\
\text { in } \mathrm{Ar}\end{array}$ & [41] \\
\hline $\mathrm{SiC}, \mathrm{SiO}_{2}{ }^{\mathrm{a}}$ & Extrusion & $\begin{array}{l}\text { Honeycomb } \\
\text { cut prisms } \\
(10 \diamond 8 \diamond 8)\end{array}$ & & [42] \\
\hline $\begin{array}{l}\alpha-\operatorname{SiC}(4.5,6.7,14.5), \\
\text { Kaolin }(2.1)^{\mathrm{a}}, \text { Methyl } \\
\text { cellulose }(\mathrm{MC})^{\mathrm{b}}, \\
\text { Water }^{\mathrm{d}}\end{array}$ & Extrusion & $\begin{array}{l}16 \text { channels } \\
\text { Flat tubes } \\
(200 \diamond 50 \\
4)\end{array}$ & $\begin{array}{l}400 \mathrm{C} / 4 \mathrm{~h} \\
1200-1500 \\
{ }^{\circ} \mathrm{C} / 1 \mathrm{~h} \text { in air }\end{array}$ & [43-45] \\
\hline $\begin{array}{l}\mathrm{SiC}(0.5,3,30), \text { Sodium } \\
\text { carboxymethyl } \\
\text { cellulose }(\mathrm{Na}-\mathrm{CMC}) \\
\text { or Carbon black }(2)^{\mathrm{e}}\end{array}$ & Extrusion & $\begin{array}{l}\text { Plaques } \\
(1000-1500 \\
\diamond 8-100)\end{array}$ & $\begin{array}{l}800-1100 \\
{ }^{2} \mathrm{C} / 3 \mathrm{~h} ; \\
2200-2300 \\
{ }^{\circ} \mathrm{C} \text { in } \\
\text { vacuum }\end{array}$ & {$[46,47]$} \\
\hline $\begin{array}{l}\mathrm{SiC}(0.4,0.6) \\
\text { Polyethersulfone } \\
(\mathrm{PES})^{\mathrm{b}}, \mathrm{N} \text {-methyl-2- } \\
\text { pyrrolidone (NMP) }{ }^{\mathrm{d}} \text {, } \\
\text { Water }\end{array}$ & $\begin{array}{l}\text { Dry-wet } \\
\text { spinning } \\
\text { @ } 2 \text { bar }\end{array}$ & $\begin{array}{l}\text { Hollow } \\
\text { fibers }(\sim 1.8 \\
\text { outer } \varnothing \\
\sim 0.5 \text { thick, } \\
\sim 50 \text { long) }\end{array}$ & $\begin{array}{l}1000-1500 \\
{ }^{\circ} \mathrm{C} / 3 \mathrm{~h} \text { in } \mathrm{Ar} \\
\text { or } \mathrm{N}_{2} ; 1790 \\
\mathrm{C} / 6 \mathrm{~h} \text { in } \\
\mathrm{Ar} ; 2075 \\
\mathrm{C} / 0.75 \mathrm{~h} \text { in } \\
\mathrm{Ar}\end{array}$ & [48] \\
\hline $\begin{array}{l}\beta(\alpha)-\mathrm{SiC}(0.13), \mathrm{Al}_{2} \mathrm{O}_{3}{ }^{\mathrm{a}} \\
\mathrm{PVA}^{\mathrm{b}}, \text { Ethylene } \\
\text { glycol }^{\mathrm{b}} \text {, Darvan } \mathrm{C}^{\mathrm{c}}\end{array}$ & $\begin{array}{l}\text { Slip } \\
\text { casting }\end{array}$ & $\begin{array}{l}\text { Tubes and } \\
\text { disks }\end{array}$ & $\begin{array}{l}8000^{-} \mathrm{C} / 1 \mathrm{~h} \\
\text { in } \mathrm{Ar} ; 1600 \\
{ }^{\circ} \mathrm{C} \text { in } \mathrm{Ar}\end{array}$ & {$[49,50]$} \\
\hline $\begin{array}{l}\mathrm{SiC}(0.14), \alpha-\mathrm{Al}_{2} \mathrm{O}_{3} \\
(0.14)^{\mathrm{a}}, \mathrm{Y}_{2} \mathrm{O}_{3}(0.08)^{\mathrm{a}}, \\
\text { Water }^{\mathrm{d}}\end{array}$ & $\begin{array}{l}\text { Slip } \\
\text { casting }\end{array}$ & & $\begin{array}{l}1400,1500, \\
\text { or } 17000^{\star} \mathrm{C} / \\
2 \mathrm{~h} \mathrm{@} 39 \\
\mathrm{MPa} \text { in } \mathrm{Ar}\end{array}$ & [51] \\
\hline $\operatorname{SiC}(5), \mathrm{PEG}^{\mathrm{b}}, \mathrm{MC}^{\mathrm{b}}$ & $\begin{array}{l}\text { Tape } \\
\text { casting }\end{array}$ & $\begin{array}{l}\text { Tapes } \\
(0.32-0.38\end{array}$ & $\begin{array}{l}500{ }^{\star} \mathrm{C} / 1.5 \\
\mathrm{~h} ; 15000^{\star} \mathrm{C} /\end{array}$ & [52] \\
\hline $\begin{array}{c}\alpha-\operatorname{SiC}(0.40), \mathrm{Al}_{2}{ }^{\mathrm{a}}, \\
\mathrm{Y}_{2} \mathrm{O}_{3}{ }^{\mathrm{a}}, \text { Gelatin }\end{array}$ & $\begin{array}{l}\text { Gel/freeze } \\
\text { casting } \\
@ \\
10 \text { or } \bullet 70 \\
\mathrm{C}\end{array}$ & $\begin{array}{l}\text { thick) } \\
\text { Disks ( } 70 \varnothing \\
\text { 10), tubes, } \\
\text { honeycombs }\end{array}$ & $\begin{array}{l}1 \mathrm{~h} \text { in } \mathrm{N}_{2} \\
600 \% \mathrm{C} / 2 \mathrm{~h}, \\
18000^{\star} \mathrm{C} / 2 \mathrm{~h} \\
\text { in } \mathrm{Ar}\end{array}$ & {$[23,53]$} \\
\hline $\begin{array}{l}\alpha \text {-SiC }(0.5), \mathrm{B}_{4} \mathrm{C}(1)^{\mathrm{a}}, \\
\text { Carbon black }(0.2)^{\mathrm{a}}, \\
\text { AM pMBAM pAPS } \mathrm{p} \\
\text { TEMED }^{\mathrm{i}}, \mathrm{TMAH}^{\mathrm{C}}, \\
\text { PVP }^{\mathrm{c}}, \text { Ovalbumin }^{9}, \\
\text { PAA }^{\dagger}\end{array}$ & $\begin{array}{l}\text { Gel } \\
\text { casting }\end{array}$ & $\begin{array}{l}\text { Foam bricks } \\
(110 \diamond 70 \diamond \\
25)\end{array}$ & $\begin{array}{l}14000^{\star} \mathrm{C} / \\
0.5 \mathrm{~h} \text { in } \\
\text { vacuum; } \\
2150^{\star} \mathrm{C} / 1 \mathrm{~h} \\
\text { in } \mathrm{Ar}\end{array}$ & [54] \\
\hline
\end{tabular}

Blank spaces correspond to unavailable data.

a sintering aid.

${ }^{\mathrm{b}}$ binder/plasticizer.

${ }^{c}$ dispersant.

${ }^{d}$ solvent/liquid medium.

e pressing aid/lubricant.

${ }^{\dagger}$ pore former.

${ }^{g}$ surfactant.

${ }^{\mathrm{h}}$ reinforcing agent.

i gel casting additives.

j coagulant.
A variable combination of $\mathrm{SiC}$ powder composition, particle size and sintering additives has been employed for the preparation of $\mathrm{SiC}$ and $\mathrm{SiC}$ composite substrates as listed in Table 1. The most commonmaterials are $\alpha$ and $\beta$ phases of SiCas $\alpha$-SiC and $\beta$-SiC. The $\alpha$-SiChas hexagonal crystal phase and is generally formed at temperatures higher than 1700 ${ }^{-} \mathrm{C}$ whilst the $\beta$-SiC has a cubic crystal phase formed at temperatures below $1700{ }^{\circ} \mathrm{C}$ [55]. SiC mean particle sizes varied in the range of 30 $300 \mu \mathrm{m}$. As a general rule in porous ceramics, the larger the initial particle size, the larger is the pore size formed. In some cases, fine and coarse SiC particles were used in order to produce macroporous $\left(d_{p}>50\right.$ $\mathrm{nm}$ ) substrates. This allowed the improvement of packing small and large particles together for the preparation of green ceramic bodies [40]

and a suitable technique to control the pore size of substrates. SiC and mullite whiskers were eventually used as reinforcing agents when packed with $\mathrm{SiC}$ and/or ceramic oxide particles.

The preparation of pure $\mathrm{SiC}$ substrates was limited to a few reports only, as listed in Table 1. The majority of the substrates produced were $\mathrm{SiC}$ composites and, apart from boron carbide $\left(\mathrm{B}_{4} \mathrm{C}\right)$, the majority of the substrates were mixed with oxide ceramics such as $\mathrm{Al}_{2} \mathrm{O}_{3}, \mathrm{ZrO}_{2}, \mathrm{Y}_{2} \mathrm{O}_{3}$, $\mathrm{MgO}, \mathrm{CaO}, \mathrm{SiO}_{2}$, mullite and kaolin. These oxides were mainly used as sintering aids for promoting densification through liquid phase sintering, which tend to modify grain boundary and surface energies, thus favoring mass diffusion rates during sintering. Further, these oxides had different particle sizes as compared to the SiC powders, also focusing on pore size control of substrates. Glass frit was employed as an alternative sintering aid for the production of composite substrate, though as a silica-based glass powder, it was also used as a binding agent.

Binders and plasticizers were also needed, such as polyvinyl alcohol (PVA), cellulose-based compounds (methyl cellulose, MC, and carboxymethyl cellulose, CMC), ethylene and polyethylene glycol (PEG).

Binders and plasticizers were commonly added to make pressing and/or extrusion feasible. Binders such as PVA increase the mechanical strength of green bodies [56]. Plasticizers such as PEG reduce viscosity and allow the preparation of flexible ceramic pastes, and are generally used for the preparation of composite and laminar ceramics [57].

In most cases, uniaxial pressing (see Table 1) at room temperature was used to shape the geometry of SiC substrates at pressures between 8 and $117 \mathrm{MPa}$. The majority of the work reported using uniaxial pressing was for the preparation of disk geometries with varying dimensions of 20-50 mm diameter and 3-10 mm thick. The smaller diameter disk had the lowest thickness and vice-versa. As uniaxial pressing brings the particles together and increase packing density, many of the disk preparation methods contained $\mathrm{SiC}$ particles with sintering agents (e.g., oxide ceramics). The uniaxial pressing was also used to prepare bar (also strip) geometries with typical thickness varying from 3 to $16 \mathrm{~mm}$ and width/length in the range of $25-65 \mathrm{~mm}$, In order to facilitate uniaxial
pressing, 1 ubricants such as oleic acid or paraffin were used as pressing aids.

Many bars and strips contained sintering agents, in addition to binders (such as PVA) and pore formers (such as petroleum coke). Tubes were also produced by the uniaxial method with typical dimensions of $12 \mathrm{~mm}$ outer diameter, $3 \mathrm{~mm}$ thick and $40 \mathrm{~mm}$ long. Tubes required binders and plasticizers in order to maintain the production of green tubular geometries. A few examples for the preparation of $\mathrm{SiC}$ composite substrates include the use of cold isostatic pressing (CIP) for better consolidation at the green state in pressure ranges from 100 to $400 \mathrm{MPa}$. Hot pressing at $1800^{\circ} \mathrm{C}$ for $2 \mathrm{~h}$ under a pressure of $30 \mathrm{MPa}$ was also performed, for simultaneous substrate shaping and sintering.

SiC composite plastic forming was mostly carried out by extrusion, resulting typically in tubular geometries with outer diameter of $6 \mathrm{~mm}$, thickness of $2 \mathrm{~mm}$, and lengths between 100 and $600 \mathrm{~mm}$. Honeycomb prisms (10 $1 \mathrm{~mm}$ ) were also manufactured by extrusion, as well as multichannel flat tubes (200504 $4 \mathrm{~m})$ or plaques (1000-1500 8 $\checkmark 100 \mathrm{~mm})$. Alternatively, hollow fibers $(\sim 1.8 \mathrm{~mm}$ outer diameter, $\sim 0.5 \mathrm{~mm}$ thick, $\sim 50 \mathrm{~mm}$ long) were prepared by dry-wet spinning at 2 bar. In the case of hollow fibers, this process is also known as phase 
inversion, as water coagulates the polymeric binder [58,59]. The coagulation is essential to maintain the hollow fiber geometry during spinning. Slip and gel casting methods were also used, whilst the latter was aided by gelatin compounds. Process/shape variations were reported for the production of honeycombs by gel/freeze casting and foam bricks (110 $250 \mathrm{~mm})$ by gel casting.

Thermal treatment temperatures varied from low as $450^{\circ} \mathrm{C}$ to as high as $2250^{\circ} \mathrm{C}$. Lower temperatures are generally applied for a pre-sintering conditioning of substrates. However, the majority of the heat treatment temperatures in Table 1 are in excess of $1000^{\circ} \mathrm{C}$. These high temperatures allow for the formation of necks in ceramic particles during sintering, thus strengthening the mechanical stability of the $\mathrm{SiC}$ or $\mathrm{SiC}$ composite substrate. For instance, SiC particles in composites (with $\mathrm{Al}_{2} \mathrm{O}_{3}$ and $\mathrm{Y}_{2} \mathrm{O}_{3}$ ) required higher sintering temperature $\left(1700^{\circ} \mathrm{C}\right)$. In the case that the sintering temperature was raised from 1700 to $1900{ }^{\circ} \mathrm{C}$, the mechanical strength increased threefold from $\sim 200$ to $\sim 600 \mathrm{MPa}$ [60]. Hence, mechanical strength is the reason that many $\alpha$-SiC-based composite substrates were sintered at temperatures in excess of $1700^{\diamond} \mathrm{C}$, though the trade-off is densification, which must be counteracted by the purpose of producing porous substrates.

In order to address the problem of densification at high temperatures, many research groups added pore forming agents into the precursor mixtures such as phenolic resin, polystyrene (PS), poly(methyl methacrylate) (PMMA), poly(acrylic acid) (PAA), petroleum coke, activated carbon, graphite, surfactants or carbon black. In the case that air was used in the thermal treatment at high temperatures, all these pore forming agents are eventually fully burnt off from the matrix of the $\mathrm{SiC}$ composites, forming $\mathrm{CO}_{2}$. Even the most resistant carbon structure (i.e., graphite) is fully combusted in air at $800{ }^{\circ} \mathrm{C}$ [61]. Hence, the voids left by the combustion of carbon-based materials result in porous structures.

In the case of thermal treatment using non-oxidizing atmospheres (i. e., $\mathrm{He}, \operatorname{Ar}$ or $\mathrm{N}_{2}$ ) many of the volatile compounds in the carbon materials evaporate from the substrate under thermal treatment. For instance, the carbonization (in $\mathrm{N}_{2}$ and up to $700{ }^{\circledR} \mathrm{C}$ ) of phenolic resins, phenol and other volatile groups [62] leave the material leading the matrix to retain almost pure carbon. As the graphitization of carbon starts at $1700^{\circ} \mathrm{C}$ [63], possibly graphite structures are generated in the SiC composites containing carbon pore forming agents for sintering temperatures $>1700^{\circ} \mathrm{C}$. Again, the issue of high temperature sintering is densification of the substrate. This problem can be easily addressed by a post-sintering in air (oxidizing atmosphere) up to $800^{\circ} \mathrm{C}$, where any carbon (and/or graphite) retained in the structure of the SiC composite substrates are fully combusted.

In summary, $\mathrm{SiC}$ is a very flexible material that can be assembled as a composite with ceramic oxides and can be mixed with a number of additives such as binders, plasticizers and pore forming agents. In addition, the $\mathrm{SiC}$ flexibility is reflected in a range of ceramic processing such as uniaxial pressing, extrusion, slip/tape casting and dry/wet spinning. These ceramic processes permitted the production of a number of geometries/shapes, such as disks, bars, tubes, hollow fibers, multichannel and honeycomb porous substrates. Heating programs with varying ramp rates and dwell times were used to dry out solvents or desorbed liquids, to burn off organic additives (including pore formers) and for curing/pyrolysis similar to conventional oxide ceramics. Many advantages are conferred by using $\mathrm{SiC}$ with other materials, where temperature and heat treatment temperature can deliver desired porosity and mechanical properties.

\subsection{Filters}

Both $\alpha$-SiC and $\beta$-SiC powders were used as starting materials to prepare filters as substrates as listed in Table 1. Substrates containing $\alpha$-SiC $(0.45 \mu \mathrm{m})$ resulted in aggregated grains (Fig. 2a) showing the formation of interconnected porous network. It is also observed that the $\mathrm{SiC}$ particles of similar size were bonded at the contacting points by welldeveloped necks. $\alpha$-SiC $(1.7 \mu \mathrm{m})$ consisted of large platelet grains formed in-situ from $\beta$-SiC powders mixed with a small ( $0 \%$ ) amount of $\alpha$-SiC powders (Fig. 2b), which tend to reduce the flexural strength due to increased pore sizes [24]. Fig. 2c presents an image of a substrate with an interesting binary pore size formation (large and small pores), also known as hierarchical structure. This SiC substrate was derived from macrocellular preceramic polymers (polycarbosilane and poly(vinyl) silazane) combined with sacrificial porogens (ultra-high molecular weight polyethylene microbeads) [64].

The flexibility of tailoring structures in $\mathrm{SiC}$ substrates as filters is further demonstrated in Fig. 3, which shows pore size versus pore volume for high and low values reported in the same publication. It is observed that there is a cluster of results ranging from 0.5 to $100 \mu \mathrm{m}$ in pore size and $25-73 \%$ in pore volume. These results reflect different starting powders/precursors and preparation/processing methods. For instance, the larger the $\mathrm{SiC}$ and other particles are, the larger is the pore size and volume. Larger particles also form coarser SiC filters. The use of pore formers, which can be burnt out, also increased these two important structural parameters. By the same token, smaller particle sizes or mixing smaller particles with larger particles resulted in smaller pore sizes and pore volumes. The very large pore sizes $(>100 \mu \mathrm{m})$ and pore volumes $(>90 \%)$ are associated with the use of large porogenic agents, whilst the smaller pore sizes $(<0.2 \mu \mathrm{m})$ and pore volumes $(<35 \%)$ are formed by the use of very fine powders.

Fig. 4 displays a limited number of flexural strength versus porosity results for $\mathrm{SiC}$ or $\mathrm{SiC}$ composite substrates available in the literature. The data is very scattered, given a clear indication that the starting powders/ precursors used ( $\mathrm{SiC}$ particle size and reinforcing agents) in addition to the processing and sintering conditions tend to affect the final mechanical properties. Nevertheless, a few trends are clearly observed. The first trend is that for the same sintering temperature, the flexural strength is inversely proportional to porosity. A second trend is that for

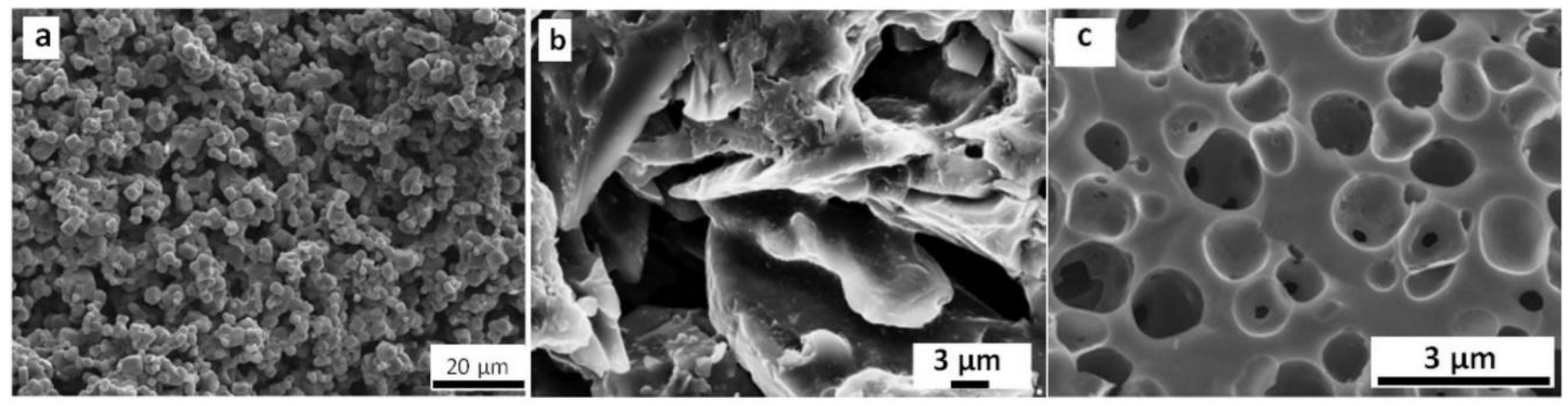

Fig. 2.SEM images (a) $\alpha$-SiC and (b) $\alpha$-SiC formed in-situ from $\beta$-SiC wit $10 \% \alpha$-SiC powders by sintering at $1950{ }^{\star} \mathrm{C}$ [24]; (c) hierarchical SiC using ultra-high molecular weight polyethylene powder (UHMW-PE) containing allyl-hydridopoly-carbosilane (AHPCS) [ 64]. 


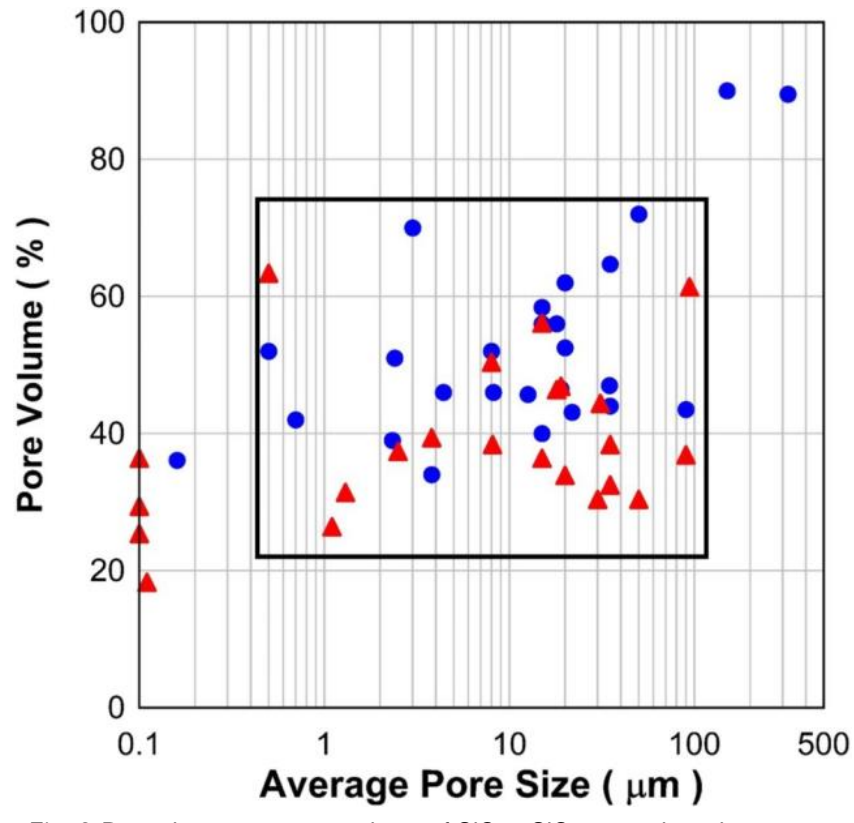

Fig. 3.Pore size versus pore volume of $\mathrm{SiC}$ or $\mathrm{SiC}$ composite substrates.

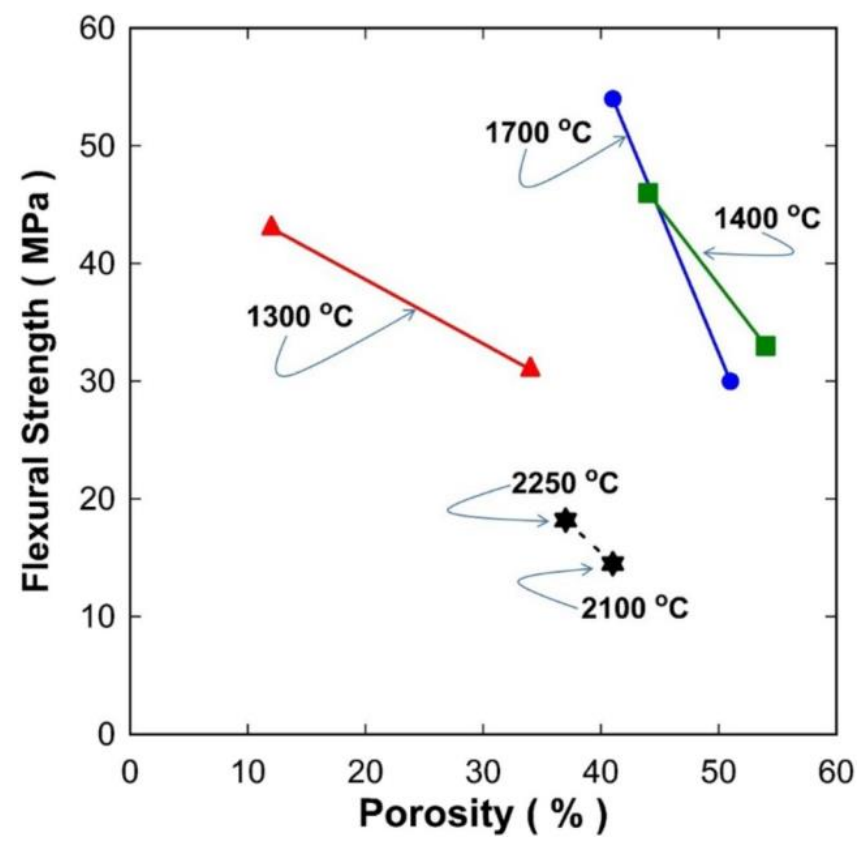

Fig. 4. Flexural strength versus porosity of $\mathrm{SiC}$ and $\mathrm{SiC}$ composite substrates $[37,43,47]$.

the same material, increasing the sintering temperature decreases porosity resulting in increased flexural strength. These results clearly indicate that increasing the sintering temperature tends to densify porous materials, which in turn increases the bonding between particles and leads to high flexural strength, as reported by Tamari et al. [60] for SiC composite materials.

\subsection{Top layer coating for filters and membranes}

Table 2 lists representative information on the preparation of SiC filters and membranes, where top layers are coated on porous substrates. The majority of the methods used to deposit top layers on substrates were slip casting or dip coating, though spray coating was also reported.
Table 2

$\mathrm{SiC}$ top layer processing parameters for SiC filters and membranes.

\begin{tabular}{|c|c|c|c|c|}
\hline $\begin{array}{l}\text { Starting powders, polymer } \\
\text { precursors and additives } \\
\text { (mean particle size in } \mu \mathrm{m} \text { ) }\end{array}$ & Coating & $\begin{array}{l}\text { Thickness } \\
(\mu \mathrm{m})\end{array}$ & $\begin{array}{l}\text { Thermal } \\
\text { treatments }\end{array}$ & Ref. \\
\hline$\beta$-SiC (0.03), Acetone ${ }^{e}$ & $\begin{array}{l}\text { Slip } \\
\text { casting }\end{array}$ & & $1950{ }^{\circ} \mathrm{C}$ in $\mathrm{Ar}$ & [16] \\
\hline $\begin{array}{l}\text { SicC, Allyl-hydridopoly- } \\
\text { carbosilane (AHPCS) } \\
\text { Hexane }^{e}\end{array}$ & $\begin{array}{l}\text { Dip } \\
\text { coating }\end{array}$ & & $\begin{array}{l}400^{\circ} \mathrm{C} / 1 \mathrm{~h} \\
600-16000^{\circ} \mathrm{C} / \\
2 \mathrm{~h} \text { in } \mathrm{Ar}\end{array}$ & {$[17]$} \\
\hline $\begin{array}{l}\text { SiC, } \text { AHPCS }^{d,} \text { Acetone } \\
\text { Hexane }\end{array}$ & $\begin{array}{l}\text { Slip } \\
\text { casting, } \\
\text { Dip } \\
\text { coating }\end{array}$ & $\sim 2$ & $\begin{array}{l}4000^{\star} \mathrm{C} / 1 \mathrm{~h} ; \\
750^{\star} \mathrm{C} / 2 \mathrm{~h} \text { in } \\
\text { Ar; } 450^{\star} \mathrm{C} / 2 \mathrm{~h} \\
\text { in air }\end{array}$ & [18] \\
\hline $\begin{array}{l}\mathrm{SiC}, \text { AHPCS }^{\mathrm{d},} \text { Acetone5, } \\
\text { Hexane5, Polystyrene } \\
(\mathrm{PS})^{\dagger}\end{array}$ & $\begin{array}{l}\text { Slip } \\
\text { casting, } \\
\text { Dip } \\
\text { coating }\end{array}$ & $\sim 7$ & $\begin{array}{l}4000^{\star} \mathrm{C} / 1 \mathrm{~h} ; \\
750^{\star} \mathrm{C} / 2 \mathrm{~h} \text { in } \\
\text { Ar; } 450^{\star} \mathrm{C} / 2 \mathrm{~h} \\
\text { in air }\end{array}$ & [19] \\
\hline $\begin{array}{l}\beta-S i C(0.1-0.2), S i C \\
\text { nanofibers, AHPCS } \\
\text { Toluene }^{e}, \text { Hexane }^{e}, \text { PS }^{\dagger}\end{array}$ & $\begin{array}{l}\text { Slip } \\
\text { casting, } \\
\text { dip } \\
\text { coating }\end{array}$ & $\sim 10$ & $\begin{array}{l}4000^{\star} \mathrm{C} / 1 \mathrm{~h} ; \\
750^{\star} \mathrm{C} / 2 \mathrm{~h} \text { in } \\
\text { Ar; } 4500^{\star} \mathrm{C} / 2 \mathrm{~h} \\
\text { in air }\end{array}$ & [28] \\
\hline $\begin{array}{l}\alpha-\operatorname{SiC}(0.4), \text { AHPCS }^{d}, \\
\text { Hexane }^{\mathrm{e}}, \text { Tetradecane }^{\mathrm{e}}\end{array}$ & $\begin{array}{l}\text { Dip } \\
\text { coating }\end{array}$ & $8-22$ & $\begin{array}{l}400^{\circ} \mathrm{C} / 1 \mathrm{~h} \\
750^{\circ} \mathrm{C} / 2 \mathrm{~h} \text { in } \\
\mathrm{Ar}\end{array}$ & [29] \\
\hline $\begin{array}{c}\mathrm{SiC}(10), \mathrm{MC}^{\mathrm{b}} \text { in water }{ }^{\mathrm{e}}, \mathrm{SiC} \\
\text { whiskers; } \mathrm{CaaO}^{\mathrm{a}}, \mathrm{ZrO}^{2{ }^{2}}{ }_{g}\end{array}$ & $\begin{array}{l}\text { Spray } \\
\text { coating }\end{array}$ & $125-200$ & C/2 h in air; & [32] \\
\hline Mullite (1), TL-56NQ & $\begin{array}{l}@ 0.2- \\
0.3 \\
\mathrm{MPa}\end{array}$ & & $\begin{array}{l}\text { 1350-1550 } \\
\mathrm{C} / 4 \mathrm{~h} \text { in } \mathrm{Ar}\end{array}$ & \\
\hline $\begin{array}{l}\mathrm{SiC}(22), \mathrm{B}_{4} \mathrm{C}(1)^{\mathrm{a}}, \mathrm{PVA}^{\mathrm{b}}, \\
\text { Tetramethylammonium } \\
\text { hydroxide }(\mathrm{TMAH})^{\mathrm{c}}, \\
\text { Water }^{\mathrm{e}}\end{array}$ & $\begin{array}{l}\text { Dip } \\
\text { coating }\end{array}$ & $\sim 100$ & $2200-2250^{\circ} \mathrm{C}$ & $\begin{array}{l}{[38,} \\
39]\end{array}$ \\
\hline $\begin{array}{l}\text { SiC }(0.55 \mu \mathrm{m}), \text { Water }{ }^{\mathrm{e}} \text {, Iso- } \\
\text { propyl alcohol (IPA) })^{\mathrm{e}} \\
\text { PVA }^{\mathrm{b}}, \mathrm{PEG}^{\mathrm{b}}, \text { Darvan } \mathrm{CN}^{\mathrm{C}}\end{array}$ & $\begin{array}{l}\text { Dip } \\
\text { coating }\end{array}$ & $5-30$ & $\begin{array}{l}900 \text { to } 1300 \\
\mathrm{C} / 1 \mathrm{~h}\end{array}$ & $\begin{array}{l}{[44,} \\
45]\end{array}$ \\
\hline $\begin{array}{l}\mathrm{SiC}(0.5 \text { and } 3 \mu \mathrm{m}), \mathrm{Na}- \\
\mathrm{CMC}^{\mathrm{b}}, \text { Poly }(\text { acrylic acid }) \\
(\text { PAA })^{\mathrm{e}}\end{array}$ & $\begin{array}{l}\text { Dip } \\
\text { coating }\end{array}$ & 60 & $\begin{array}{l}1900-2000{ }^{\star} \mathrm{C} \\
\text { in vacuum }\end{array}$ & {$[46]$} \\
\hline $\begin{array}{l}\mathrm{SiC}(0.5 \text { and } 3 \mu \mathrm{m}), \mathrm{Na}- \\
\mathrm{CMC}^{\mathrm{b}}\end{array}$ & $\begin{array}{l}\text { Spray } \\
\text { coating }\end{array}$ & 60 & $\begin{array}{l}1850-1950 \\
\mathrm{C} / 1 \mathrm{~h} \text { in }\end{array}$ & {$[47]$} \\
\hline $\begin{array}{l}\beta(\mathcal{P A A})_{i C}^{\mathrm{e}}(0.13 \mu \mathrm{m}), \mathrm{Al}_{2} \mathrm{Q}^{\mathrm{a}}, \\
\mathrm{PVA}^{\mathrm{b}}, \text { Ethylene glycol } \\
\text { Darvan } \mathrm{C}^{\mathrm{c}}\end{array}$ & $\begin{array}{l}\text { Slip } \\
\text { casting }\end{array}$ & $\sim 50$ & $\begin{array}{l}\text { yagum } / 1 \text { hin } \\
\text { Ar; } 1400- \\
1500{ }^{\circ} \mathrm{C} \\
\text { in } \mathrm{Ar}\end{array}$ & [49] \\
\hline $\begin{array}{l}\text { Poly(dimethylsilane) } \\
\text { (PMS) }^{d}, p-\text { Xylene }{ }^{e}\end{array}$ & $\begin{array}{l}\text { Dip } \\
\text { coating }\end{array}$ & & $\begin{array}{l}460^{\star} \mathrm{C} / 14 \mathrm{~h} \text { in } \\
\text { Ar; } 2000^{\circ} \mathrm{C} / 1 \mathrm{~h} \\
\text { in air; } 300- \\
950^{\circ} \mathrm{C} \text { in } \\
\mathrm{Ar}\end{array}$ & {$[50]$} \\
\hline
\end{tabular}

${ }^{\text {a }}$ sintering aid.

${ }^{\mathrm{b}}$ binder/plasticizer.

${ }^{c}$ dispersant.

${ }^{\mathrm{d}}$ pre-ceramic polymer.

e solvent/liquid medium.

f pore former.

${ }^{\mathrm{g}}$ defoaming agent.

In the simplest case, SiC powder was dispersed in water forming a coating suspension. Variations of the precursor solution in Table 2 included the addition of dispersant (Darvan and TMAH), binder (PVA, PEG, ethylene glycol, CMC) or an alternative liquid medium (PAA). Preceramic polymers, such as allyl-hydridopoly-carbosilane (AHPCS) or poly(dimethylsilane) (PMS) dissolved in an appropriate solvent, were also used for top-layer coating. These additives were added to coating solution to adjust rheological parameters.

Subsequently to coating, the coated substrates were exposed to heat treatment to provide a good adherence of the top layers with the substrate, whilst conferring the required pore size of the sintered top layer for separation processes. In the case of SiC top layers, the sintering temperatures are generally similar or lower than those applied for the substrates (1150-2000 $\mathrm{C}$ in $\mathrm{Ar}$, air or vacuum). In the case of polymer- 
derived SiC ceramics (i.e., AHPCS), lower temperatures were required for cross-linking and pyrolysis, typically in the range of $750-1600{ }^{\circ} \mathrm{C}$ (in $\mathrm{Ar}$ ). The primary pyrolysis of AHPCS leads to the formation of SiC. Any residual carbon can be removed in a final air oxidation heat treatment at lower temperatures $\left(\sim 800^{\circledR} \mathrm{C}\right)$.

Upon sintering, the top layer attains the required pore size control enabling the membrane to separate gas/liquid generally by size exclusion, though sorption/diffusion can also affect the separation of molecules. In the case of slip-cast or dip-coating methods, the thickness of the top layers ranged from 0.15 to $100 \mu \mathrm{m}$, though thicker layers of 125 $200 \mu \mathrm{m}$ were attained by the spray coating method. SiC membranes were prepared in the asymmetric configuration as depicted in Fig. 5a, showing a top layer (thin film) coated on a coarse porous substrate. A general rule dictates that the top layer should be as thin as possible to reduce the resistance for the permeation of gas/liquid molecules. In other words, the thinner the top layer is the higher is the flux and viceversa. Therefore, the thinner films in Table 2 are generally associated with $\mathrm{SiC}$ membranes, whilst the thicker films are those used for special applications as filters. For instance, the top layers containing SiC whiskers or those prepared using spray drying generated thicker films $(>60$ $\mu \mathrm{m})$, which were used for air filtering and soot filtering/catalysis in diesel engines.

Many of the reports involved the preparation of top layers containing two or more coated layers, where each layer is coated and sintered before adding another layer and successive sintering. This practice of multi top layer coating and sintering [68] follows a principle of reducing coating defects on thin films, which are susceptible to defect formation due to porous substrate surface roughness, environmental dust and other factors. Hence, high quality membranes are generally prepared in clean rooms to avoid environmental dust [69], whilst substrates are sanded to deliver very smooth surfaces for the coating of top layers. SiC nanofibers (Fig. 5b) and ceramic oxides (e.g. mullite, zirconia and calcium oxide) were also added to some of the coating mixtures, aiming at controlling either shrinkage or porosity during thermal treatment.

$\mathrm{SiC}$ hollow fiber membranes were produced through wet-dry spinning. Hollow fibers generally have external diameters below $1 \mathrm{~mm}$. Hence, this geometry is desirable since it allows for high aspect ratio in engineering applications, where a large number of hollow fibers can be packed in a single volume, thus delivering a high surface area ratio per volume. However, brittleness and weak mechanical strength are generally associated with ceramic hollow fibers. It is noteworthy that the $\mathrm{SiC}$ hollow fiber structural formation is characterized by macrovoids (finger-like pores) at the inner shell and a sponge-like porous region closer to the outer shell (Fig. 5c). This structure is derived from the phase inversion process imbibed during the wet-dry spinning of hollow fibers $[70,71]$. Essentially, the hollow fibers require a polymeric binder and an organic solvent mixed with the SiC powders as a precursor solution. Upon spinning, the precursor contacts the non-solvent (water) liquid through the inner shell of the hollow fibers [ 72,73]. This causes a fast solvent and non-solvent exchange resulting in the formation of fingerlike pores. Once the hollow fiber reaches a coagulation bath (generally water), then the outer shell of the hollow fiber is solvent lean, so the solvent and non-solvent exchange is minor and the structure tends to be sponge-like.

$\mathrm{SiC}$ is also a flexible processing material for the production of top layers with dimensions as thin as $2 \mu \mathrm{m}$ and up to $200 \mu \mathrm{m}$ as listed in Table 2. The SiC precursor solutions for the preparation of top layers were as simple as $\mathrm{SiC}$ powders dispersed in water, or contained a series of additives such as binders and sintering agents, in addition of whiskers. Further processing flexibility translated into preparing top layers by slip casting, dip coating, spray drying and dry-wet spinning. After heat treatment, $\mathrm{SiC}$ top layers confer the final properties for separation processes as filters and/or membranes.

\section{Gas and liquid transport and separation properties}

\subsection{SiC filters}

Filters are generally used for filtering particles from gas streams whose performance is measured using Darcy's permeability. In its simple form, Darcy's equation states that:

$Q^{1 / 4} \frac{k A \Delta P}{\mu L}$

where $Q$ is the flow rate $\left(\mathrm{m}^{3} \mathrm{~s}^{\otimes 1}\right), k$ is Darcy's permeability $\left(\mathrm{m}^{2}\right), A$ is the cross section area of the filter $\left(\mathrm{m}^{2}\right), \Delta P$ is the pressure drop $(\mathrm{Pa})$ along the length $L(\mathrm{~m})$ of the filter for a fluid with a dynamic viscosity $\mu(\mathrm{Pa} \mathrm{s})$. In other words, $k$ is a mass transfer coefficient, which depends on the intrinsic structural properties of filters.

Fig. 6a shows Darcy's permeability versus porosity of SiC or SiC composite filters. It is observed that as the porosity increases so does Darcy's permeability. This is shown in Fig. $6 \mathrm{a}$ as a narrow band of results. The low dispersion of values within this narrow band is generally due to structural variations of the filters in addition to experimental variations. The increase of Darcy's permeability with porosity is associated with the reduction of resistance for the flow of air or nitrogen. Hence, the smaller the porosity the higher is the resistance to flow resulting in lower Darcy's permeability and vice-versa. However, a number of results (see circle in Fig. 6a) show Darcy's permeability at least one order of magnitude higher for the same porosity. These results are unusual and, therefore, Darcy's permeability was plotted versus pore size. Fig. $6 \mathrm{~b}$ also shows that Darcy's permeability increases as a function of the pore size, although there is a significant variation, as results are scattered by up to two orders of magnitude. Nevertheless, Fig. 6b (see circle) shows that the filters with the unusual high Darcy's permeability indeed had large pore sizes. This explains that filters with high porosity and large pore size will deliver high Darcy's permeability. Darcy's permeability in Fig. 6 ranged from $\sim 10^{\$ 13}$ to $\sim 10^{\otimes 10} \mathrm{~m}^{2}$. These values are in line with those reported by Innocentini et al. [74,75] for filters, and comparable to their oxide ceramic counterparts. The pore size of filters is generally high, so filters are used for particle separation gas
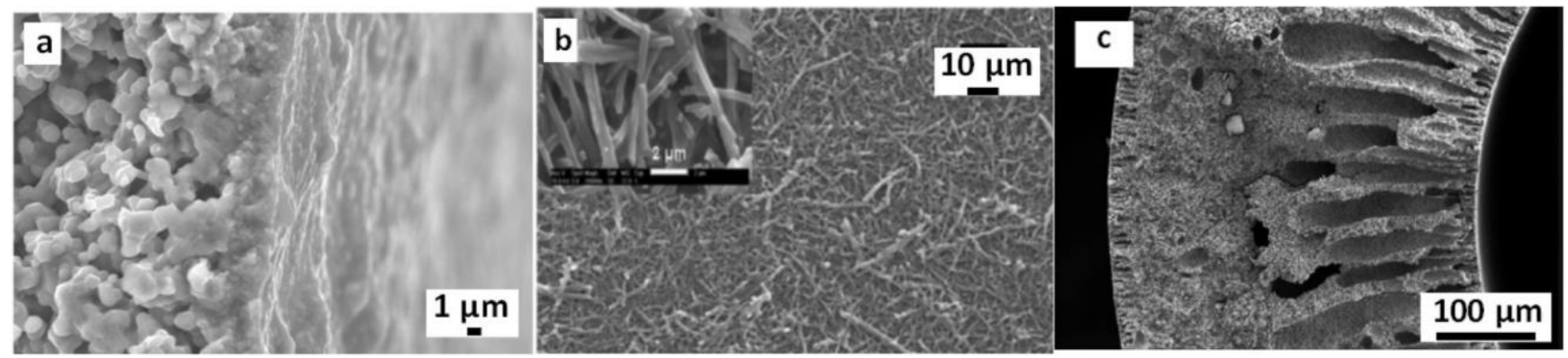

Fig. 5.SEM images of $\mathrm{SiC}$ porous microstructures: (a) asymmetric membrane with a top layer [ 67]; (b) top layer containing SiC nanofibers [28]; and (c) SiC hollow fiber [48]. 

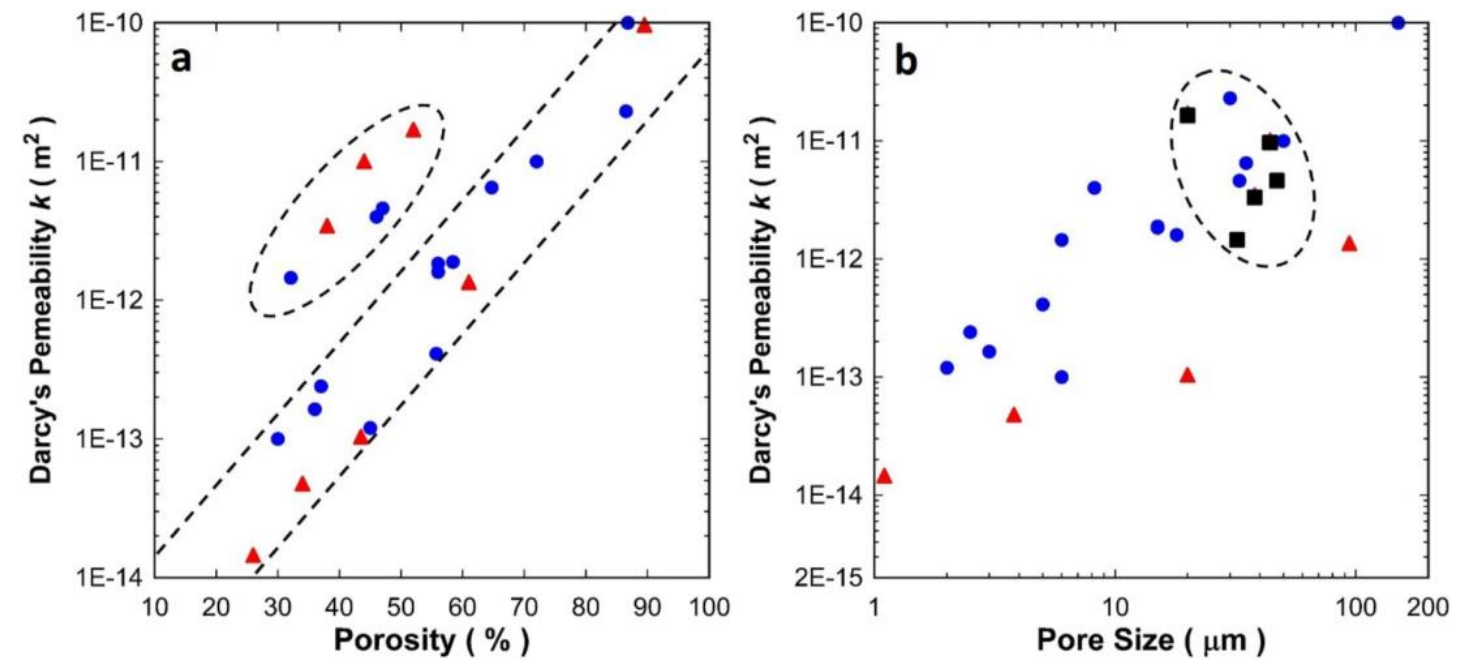

Fig. 6.Darcy's permeability versus: (a) porosity and (b) pore size [ 20,23-27,31,35,36,38-40,53,54,64,65].

streams reaching filtration efficiencies as high as $~ 99 \%$.

\subsection{SiC membranes for gas separation}

$\mathrm{SiC}$ membranes are asymmetric structures, where the SiC top layer has the capabilities to separate gases by molecular exclusion, a mechanism also known as molecular sieving. As such, the $\mathrm{SiC}$ top layer is a limiting factor and the transport of gases follows Fick's law. As gas adsorption in $\mathrm{SiC}$ generally complies with Henry's law, Fick's law can be simplified to:

$J 1 / 4 \diamond P \Delta p$

where $J$ is the flux ( $\mathrm{mol} \mathrm{m} \mathrm{m}^{\otimes 2} \mathrm{~s}^{\otimes 1}$ ), $P$ is the mass transfer coefficient (mol $\mathrm{m}^{\otimes 2} \mathrm{~s} \mathrm{~Pa}^{\otimes 1}$ ) for a $\Delta p$ pressure gradient ( $\mathrm{Pa}$ ) applied across the membrane. The mass transfer coefficient $P$ is the most used parameter to compare membranes, as it is a pressure-normalized parameter.

Another excellent yard stick to compare the performance of membranes is a gas selective factor $\left(S_{A / B}\right)$, also known as permselectivity. This factor is generally used for comparing the permeation of pure or single gases ( $A$ or B) through the membrane as set out in Eq. (3). In this case, if adsorption has low coverage, the permeance of the gas with the smaller kinetic diameter $\left(d_{k} 1 / 4 A\right)$ is higher than that of the gas with the larger kinetic diameter $\left(d_{k} 1 / 4 B\right)$, so $P_{A}>P_{B}$.

$\stackrel{S_{A B}}{=}{ }^{1 / 4} \frac{P_{A}}{P_{B}}$

Fig. 7 displays a Robeson plot of $\mathrm{SiC}$ membranes showing the upper bound for $\mathrm{He} / \mathrm{Ar}$. It is observed that a few results with very large permeances $\left(>1 \otimes 10\right.$ mol m $\left.\mathrm{m}^{\otimes 1} \mathrm{~Pa}^{\otimes 1}\right)$ and low permselectivity $\mathrm{He} / \mathrm{Ar}$ values around 2 . This shows the major trade-off between production (permeance) and quality (permselectivity) in membrane technology. Generally, high permeance results in low permselecitvity and vice-versa. Nevertheless, high permeance values in porous inorganic membranes reflectlarge pores sizes, so the resistance to gas permeation reduces. Asa result, the pore sizes $\left(d_{p}\right)$ are larger than the kinetic diameter of the gases, $d_{p}>d_{k A}>d_{k B}$, so SiC membranes are unable to efficiently separate gases.

In some cases, high permeance and low selectivity can be also associated with low quality membranes, due to pin-hole defects and/or micro-cracks. A common technique to reduce thin film defects in the production of high quality membranes is multi top-layer coating. However, by adding more top layers, the thickness of the membrane increases. As gas fluxes are inversely proportional to the thickness of membrane, the penalty of adding more top layers is lower flux or

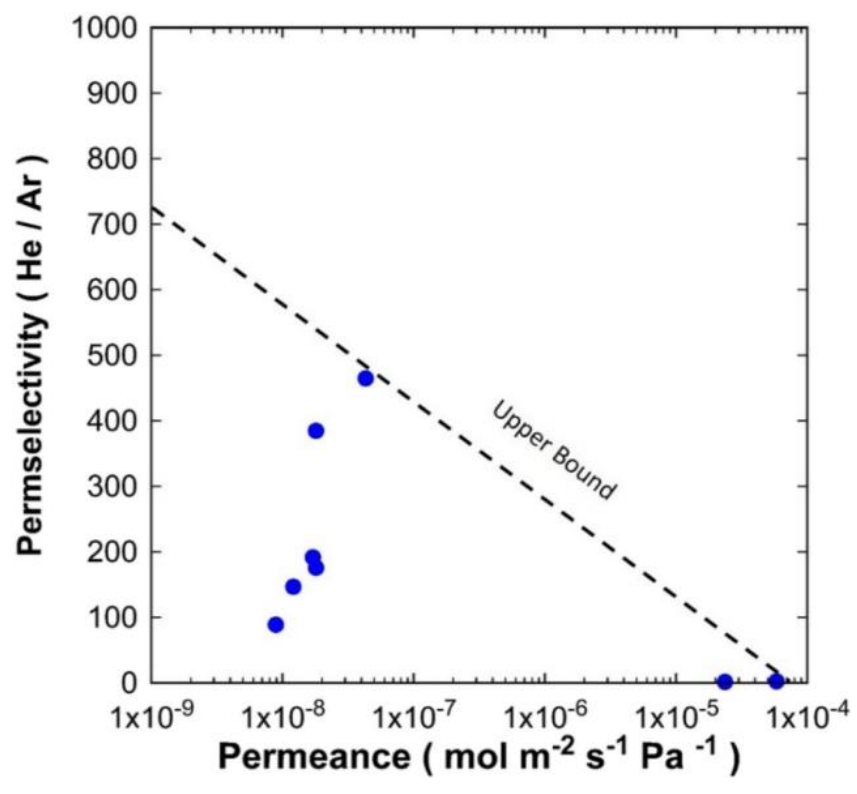

Fig. 7. Robeson plot of He/Ar permselectivity versus He permeance of SiC membranes [18,19,28,66,67].

permeance, though a major advantage is high permselectivity. This has been demonstrated by Tsotsis group [67] for SiC asymmetric membranes reporting that He permeance decreased from $\sim 4.5103$ to

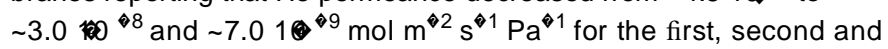
third SiC top layer, respectively. By the same token, He/Ar permselectivity increased significantly from 75 to 120 and 350 .

Fig. 7 also shows a series of $\mathrm{SiC}$ membranes delivering high $\mathrm{He} / \mathrm{Ar}$ selectivies between 89 and 465 for He permeances between $8.10 \%$ and $4.3 \otimes 8 \mathrm{~mol} \mathrm{~m} \otimes^{\otimes} \mathrm{s} \mathrm{Pa}^{\otimes 1}$. These results are also in line with a large number of high quality silica (oxide) membranes reported in the literature for gas separation [76-78]. These SiC membranes are of high quality and are generally characterized by a porous matrix in the region of ultra micropores $\left(d_{p} \sim 3 \AA\right)$. In this case, the kinetic diameter of $\mathrm{He}\left(d_{k}\right.$, $\mathrm{He}^{1 / 42.6 \AA)}$ is smaller than the $\mathrm{SiC}$ membrane average pore size and the kinetic diameter of $\operatorname{Ar}\left(d_{k, A r}\right.$ Z $\left._{4} 4 \AA\right)$, so $d_{k, H e}<d_{p}<d_{k, A r}$. This is the reason that He permeates preferentially through the SiC membrane, resulting in high permeance, whilst Ar permeation is very small and delivering low permeance.

Another important aspect of these high quality $\mathrm{SiC}$ membranes is that 
the permeation of the smaller gases increases with temperature while the permeation of the large gases decreases or remains constant with temperature. As a result, permselectivity increases with temperature as recently demonstrated by Naserifar et al. for SiC membranes [79]. In principle, the mass transfer coefficient $(P \sim D K)$ is affected by increasing the temperature, as diffusivity $D$ tends to increase and gas adsorption $K$ tends to decrease as a function of temperature. However, when the pore sizes are too small, the larger gas Ar needs more energy than the smaller gas $\mathrm{He}$ to access and diffuse through the small pores. In this case, the permeation of the gases are proportional to $e^{(-1 / T)}$, a mechanism referred to as activated transport. The activated transport model has been adapted from Fick's law by Barrer [80] for transport through micropores as follow:

$$
\stackrel{\otimes E_{a c t}}{R T}
$$

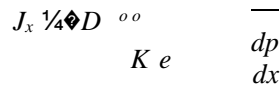

where $J_{x}$ is the flux $\left(\mathrm{mol} \mathrm{m} \mathrm{m}^{-1}\right)$ through the membrane, $D_{o}$ is a temperature independent proportionality constant associated with energy of diffusion $\left(E_{d}\right), K_{o}$ is a temperature independent proportionality constant associated with the isosteric heat of adsorption $\left(Q_{s t}\right), E_{a c t}$ is an apparent activation energy $\left(\mathrm{kJ} \mathrm{mol}^{\otimes 1}\right), R$ the gas constant $\left(\mathrm{J} \mathrm{mol}{ }^{\otimes 1} \mathrm{~K}^{\otimes 1}\right)$ and $T$ the absolute temperature (K).

Fig. 8 shows the Robeson plot for the separation of $\mathrm{H}_{2}$ to several gases. The kinetic diameter of $\mathrm{H}_{2}(\mathrm{dk} 1 / 42.89 \AA)$ is smaller than the other gases $\mathrm{CO}_{2}(3.3 \AA), \mathrm{N}_{2}(3.64 \AA), \mathrm{CH}_{4}(3.8 \AA)$ and $\mathrm{i}-\mathrm{C}_{4} \mathrm{H}_{10}(4.5 \AA)$. Although the number of results available are limited, all the permeances are close and varying between $5 \diamond 10 \diamond 9$ and $1 \diamond 10 \diamond 8 \mathrm{~mol} \mathrm{~m} \mathrm{~m}^{\diamond 1} \mathrm{~Pa}$. As the difference in size of the kinetic diameter of these gases $\left(d_{k}>3 \AA\right)$ is very small, these small differences do not justify the large variations in permselectivity ranging from $20\left(\mathrm{H}_{2} / \mathrm{N}_{2}\right)$ to $80\left(\mathrm{H}_{2} / \mathrm{i}-\mathrm{C}_{4} \mathrm{H}_{10}\right), 90\left(\mathrm{H}_{2}\right)$ $\left.\mathrm{CH}_{4}\right)$ and $97\left(\mathrm{H}_{2} / \mathrm{CO}_{2}\right)$. It should be noted that the $\mathrm{H}_{2} / \mathrm{CO}_{2}$ and $\mathrm{H}_{2} / \mathrm{CH}_{4}$ vary from $\sim 30$ to 90 and $\sim 40$ to 97 , respectively. These differences in permselectivity are directly attributed to the differences in temperaturedependentadsorption as the mass transfer coefficient $P \sim D K$. Similar to $\mathrm{SiC}$ derived carbon [81], silica [82,83] and zeolites [84,85], $\mathrm{CO}_{2}$ and hydrocarbons have certain chemical affinity to $\mathrm{SiC}$, thus demonstrating the effect of gas adsorption, especially at low temperatures. In other words, adsorption enhances permeation of gas molecules such as $\mathrm{CO}_{2}$

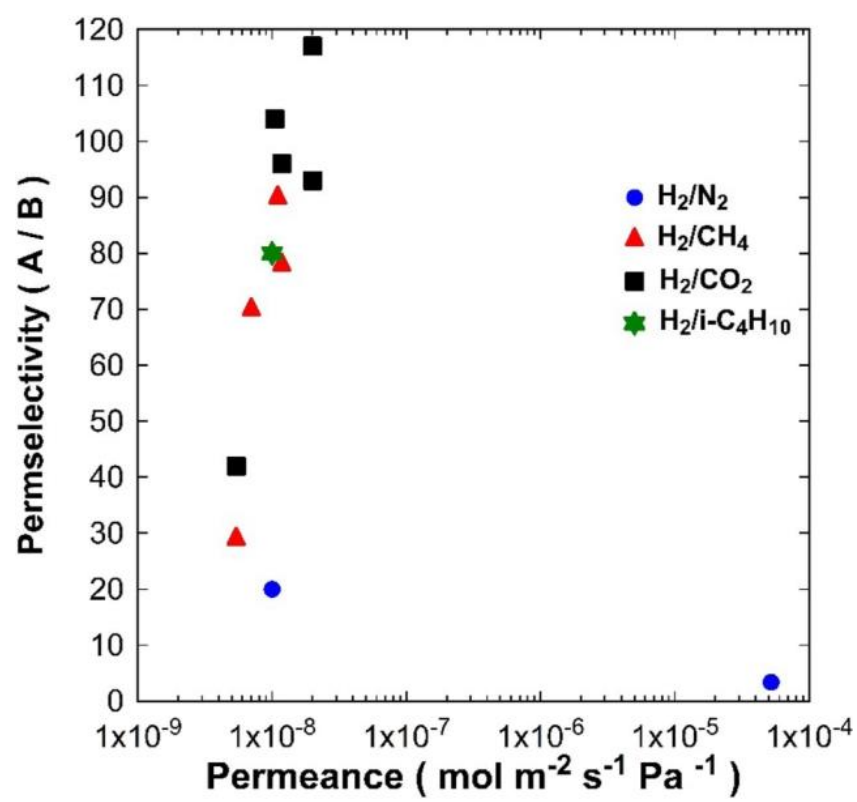

Fig. 8. Robeson plot of $A / B$ permselectivity versus $\mathrm{H}_{2}$ permeance of $\mathrm{SiC}$ membranes for $\mathrm{H}_{2} / \mathrm{CH}_{4}$ [18,19,28], $\mathrm{H}_{2} / \mathrm{CO}_{2} \quad[18,19], \quad \mathrm{H}_{2} / \mathrm{N}_{2}$ and $\mathrm{H}_{2} / \mathrm{i}-$ $\mathrm{C}_{4} \mathrm{H}_{10}[50]$. and hydrocarbon through the pores of $\mathrm{SiC}$ membranes at low temperatures, resulting in low selectivities of $\mathrm{H}_{2} / \mathrm{CO}_{2}$ and $\mathrm{H}_{2} / \mathrm{CH}_{4}$.

\subsection{SiC membranes for liquid separation}

SiC membranes have been produced mainly for ultrafiltration (UF) and microfiltration (MF) applications. The pore sizes for UF $\left(1<d_{p}<\right.$ $100 \mathrm{~nm})$ and MF $\left(100<d_{p}<500 \mathrm{~nm}\right)$ are larger than the membranes used in gas separation $\left(d_{p} \sim 3 \mathrm{~nm}\right)$. Nevertheless, Fick's law is also applicable for the transport of liquids through $\mathrm{SiC}$ membranes, which can be simplified (Eq. (2)), where the flux equals to the mass transfers coefficient times the pressure gradient applied through the membrane $(J P \Delta p)$. This equation shows that the flux of liquids through the membrane increases proportionally as a function of the pressure

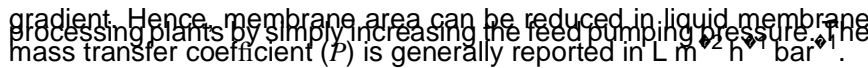

Fig. 9 displays water permeance values for commercial SiC membranes together with those reported in the literature. It is observed that commercial SiC membranes deliver higher water permeance than those reported by research groups for the same pore size. This clearly indicates that the ceramic industry has optimized the industrial production of $\mathrm{SiC}$ membranes with fine controls in the preparation of precursor solutions, in addition to extrusion processes and sintering. The limited results in Fig. 9 show a trend that increasing the pore size of the membranes directly increases water permeance. Apart for small variation in UF for commercial tubes, this trend is consistent for MF. The variations in UF could be associated with thickness of the top layers and porosity of the substrate.

SiC membranes in liquid processing allow for water permeation whilst selectively blocking other molecules and/or compounds such as solids and grease. The liquid separation industry is very broad, so depending on the process used (UF or MF) there is an array of molecules/compounds reported in literature being separated quite efficiently (>75\%). In these processes, water permeates through the SiC membrane while the retentate stream concentrates solid particles, grease and other compounds.

\section{Thermal and chemical stability}

A fundamental issue and a constant challenge for the broader use of

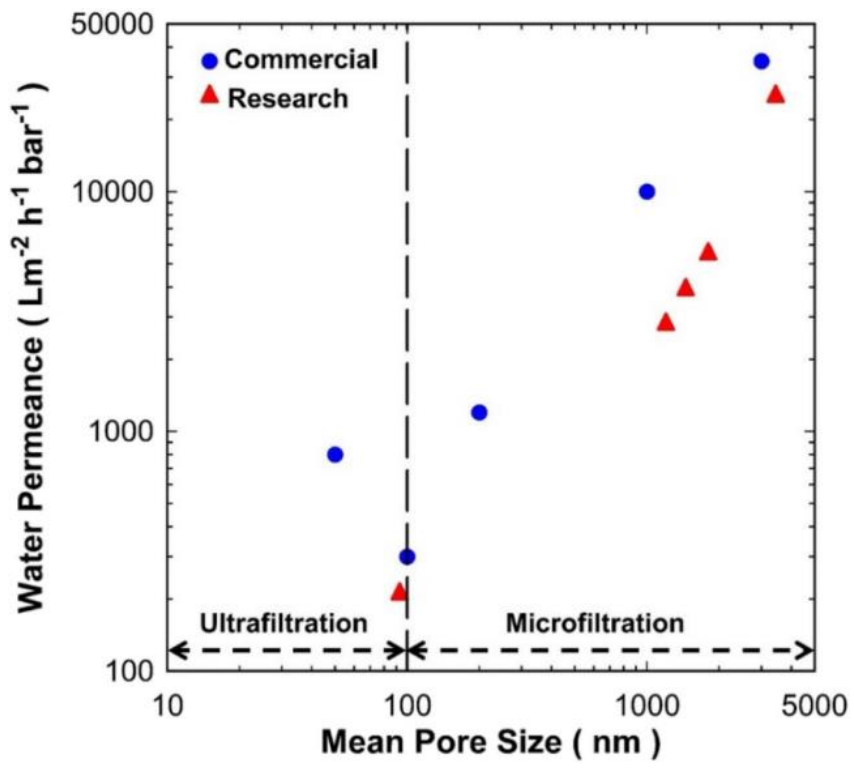

Fig. 9. Water permeance versus mean pore size for $\mathrm{SiC}$ membranes commercially available [84-86] and reported by several research groups [43,44,47]. 
filters and membranes is their stability during operation, particularly at harsh conditions (high temperature/pressure and presence of steam). Carbide-based materials are known to withstand high temperatures and may be designed to mechanically resist to pressure drops. Furthermore, thermal shock resistance may be also an advantage of non-oxide ceramics. Nevertheless, many envisaged applications of SiC filters and membranes, eventually including catalytic activity, are usually carried out at high temperature in the presence of gas streams containing water.

SiC may suffer either active or passive oxidation [89-91]. The oxidation behavior depends on the oxidizing species, temperature, total pressure and partial pressure of the oxidant. Passive oxidation occurs at high oxygen partial pressures and very high temperatures, and a protective $\mathrm{SiO}_{2}$ layer is formed according to:

$\mathrm{SiCp} 1: 5 \mathrm{O} \quad{ }_{2} \sigma_{\mathrm{g} p} \rightarrow \mathrm{SiO}_{2} \mathrm{pCO} \quad{ }_{\mathrm{g} g} \mathrm{p}$

Alternatively, active oxidation is observed at low oxygen partial pressures and high temperatures. In this case, a non-protective oxide film is formed due to formation of $\mathrm{SiO}$ vapor:

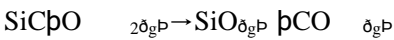

Any transformation of $\mathrm{SiC}$ to silicon oxide $\left(\mathrm{SiO}_{2}\right)$ is a concern in porous materials. The major reason is that there is a structural rearrangement, so pore sizes and pore volumes change. In turn, this affect fluxes/permeance, and very importantly permselectivity. This is a common problem in $\mathrm{SiO}_{2}$ membranes containing silanol ( $\left.\mathrm{Si}-\mathrm{OH}\right)$ groups, which are unstable in the presence of water [90-93]. Many targeted applications for $\mathrm{SiC}$ membrane involves industrial gas separation, which contain water as in humid or steam condition. Ciora et al. [17] reported that SiC membranes were stable to high-temperature air oxidation, though failed when exposed to high-temperature steam. Elyassi et al. [18] tested $\mathrm{SiC}$ membranes under mild conditions of equimolar mixture of $\mathrm{H}_{2} \mathrm{O}$ (steam) and $\mathrm{He}$ at $200{ }^{\circ} \mathrm{C}$, and reported that the membranes lasted 21 days.

A common approach to improve hydrothermal stability is to embed metal oxide with the thin-film matrix, a technique widely used for the preparation of $\mathrm{SiO}_{2}$ membranes [94,95]. Fukushima et al. [21,22,96] used this principle by adding $\mathrm{Al}_{2} \mathrm{O}_{3}$ to $\mathrm{SiC}$ in the production of substrates, which were tested for hydrogen production by steam reforming of methane at 600 and $1000{ }^{\circledR} \mathrm{C}, 4 \mathrm{~atm}$ and $\mathrm{H}_{2} \mathrm{O} / \mathrm{N}_{2}(3: 1)$ molar ratio. At $600 \mathrm{C}$, the alumina-doped support showed mass gain of $1.3 \mathrm{mg} \mathrm{cm}$, while the non-doped support showed mass gain of $0.7 \mathrm{mg} \mathrm{cm} 2$. In the doped support, pore growth was observed due to coalescence of oxidized fine particles. In contrast, the pore size of the supports without alumina was slightly reduced, due to thin silica layer formed on $\mathrm{SiC}$ particles. At $1000{ }^{\circledR} \mathrm{C}, \mathrm{SiC}$ was almost completely converted to dense $\mathrm{SiO}_{2}$, due to the viscous flow sintering of silica under water vapor.

The chemical stability of SiC substrates was also investigated under the exposure of acid or alkaline solutions. Das et al. [37] reported that $\mathrm{SiC}$ was stable in the $\mathrm{pH}$ range of $3-10$ at $90{ }^{\circ} \mathrm{C}$ for 10 days, though unstable at $\mathrm{pH} 1$ due to formation of surface siloxane groups $(\mathrm{Si}-\mathrm{O}-\mathrm{Si})$, whilst $\mathrm{SiC}$ dissolved rapidly with the formation of $\mathrm{Na}_{2} \mathrm{SiO}_{3} \mathrm{NaOH}$ when exposed to $\mathrm{NaOH}$ ( $\mathrm{pH}$ 11). Bukhari et al. [45] also found that $\mathrm{SiC}$ samples slightly degraded when exposed to acids solutions for up to 60 days at room temperature. Han et al. [33] doped $\mathrm{SiC}$ substrates $\mathrm{CaO}$ and $\mathrm{ZrO}_{2}$ and exposed them to solutions of $20 \mathrm{wt} \% \mathrm{H}_{2} \mathrm{SO}_{4}, 0.5 \mathrm{wt} \% \mathrm{HF}$ and $1 \mathrm{wt} \%$ $\mathrm{NaOH}$, respectively, at $80 \mathrm{C}$ for $96 \mathrm{~h}$. The mass loss was less than $1 \%$ for all tests, suggesting that metal oxide $\mathrm{SiC}$ samples were stable during these short time tests of approximately 4 days. Kim et al. [36] exposed glass-bonded $\mathrm{SiC}$ membranes to $\mathrm{pH}$ solutions of 3 or 11 for 63 days at room temperature. The flexural strengths of the samples gradually decreased from $\sim 80 \mathrm{MPa}$ to $\sim 60$ and $\sim 50 \mathrm{MPa}$ with the exposure to acidic or basic solutions respectively.

The effect of thermo-cycling has been investigated by several research groups. Han et al. [30] tested SiC porous filters from 30 to 800 - Candreported that the mechanical strength decreased from $\sim 10$ to $\sim 4$
MPa after 6 cold-hot cycles for non-reinforced SiC samples. By the same token, the mechanical strength of the reinforced samples reduced from $\sim 28 \mathrm{MPa}$ to $20 \mathrm{MPa}$ which became stable at this value after 18 cycles. This demonstrates the effect of reinforcing agents listed in Table 1. For instance SiC whiskers played a supporting role in hindering the crack propagation between the $\mathrm{SiC}$ grains $[97,98]$ and retained the bending strength of $14.5 \mathrm{MPa}$ after 60 cold-hot cycles (room temperature to 800 $\left.{ }^{-} \mathrm{C}\right)$ [31]. $\mathrm{SiC}$ porous substrates were exposed to sever thermal cycling by quenching at 800 to $20^{\circ} \mathrm{C}$ in air and water. Micro-cracks appeared under fast thermal stress acting, and under the more severe water quenching (Fig. 10) the mechanical strength decreased sharply during the first 10 cycles from 23 to $12.5 \mathrm{MPa}$ [99]. Under less severe air cooling, the mechanical strength also reduced though to a higher value of $17.5 \mathrm{MPa}$. Nevertheless, the mechanical strength remained stable from 10 to 60 cycles for both air cooling and water quenching.

Overall SiC substrates have shown to possess stable thermal stability. Even under severe thermal stress, $\mathrm{SiC}$ substrates were able to maintain good mechanical strength for sixty quenching cycles. These results suggest that effects at moderate thermal cycling will likely to be minimal. SiC substrates also delivered moderate chemical stability under acidic and alkaline conditions $(3<\mathrm{pH}<10)$. However, lower $\mathrm{pH}(<3)$ or higher $\mathrm{pH}(>10)$ caused irretrievable structural changes and $\mathrm{SiC}$ substrates were no longer stable. Nevertheless, steam together with moderate temperatures (>200 C) has caused serious problems demonstrating that SiC substrates are unstable under these operating conditions.

\section{Separation process applications and challenges}

\subsection{Gas separation}

SiC membranes are desirable for gas separation as the pore size can be tailored for molecular sieving applications, so the smaller gas can diffuse through the membrane pores and the larger gas diffusion is hindered to some extent. $\mathrm{SiC}$ membranes reached very high $\mathrm{He} / \mathrm{Ar}$ selectivities of values close to 500 as shown in Fig. 6, a very high separation factor indeed. However, $\mathrm{He} / \mathrm{Ar}$ separation has no significant industrial application, though separations of $\mathrm{H}_{2} / \mathrm{CO}_{2}$ are attractive as $\mathrm{H}_{2}$ is a feed gas used in the petrochemical industry, particularly derived from the water gas shift reaction [100]. In industrial applications, SiC membranes could be used in two types of $\mathrm{H}_{2}$ production set ups as depicted in Fig. 11.

The first set up (Fig. 11a) shows the $\mathrm{SiC}$ membranes separating $\mathrm{H}_{2} /$

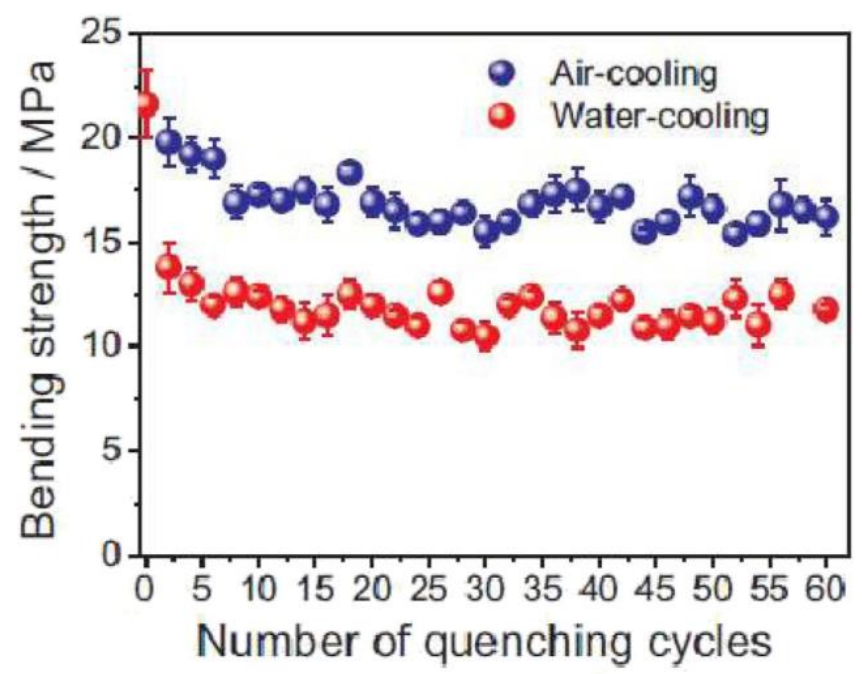

Fig. 10.Thermal stability of $\mathrm{SiC}$ porous substrates: bending strength after cyclic $1 / 4$ thermal shock at a quenching temperature of $800{ }^{\circledR} \mathrm{C}$ [33]. 
$\mathrm{CO}_{2}$ at the back end of the low temperature water gas shift reactor. The advantage here is that $\mathrm{H}_{2}$ is separated from the feed stream at moderately high temperatures $\left(\sim 250^{\circ} \mathrm{C}\right)$, so there is no need to cool down the feed stream to separate gases using conventional separation technologies such as pressure swing adsorption (PSA). Hence, the benefits are energy savings, which translate into lower operational costs (Opex). In the second set up (Fig. 11b), the SiC membranes operate as membrane reactors at the high temperature and low temperature shift reactors. As the water gas shift reaction $\left(\mathrm{H}_{2} \mathrm{pH}_{2} \mathrm{O} \rightarrow 2 \mathrm{H}_{2} \mathrm{pCO}_{2}\right)$ is equilibrium limited, by separating $\mathrm{H}_{2}$ by the $\mathrm{SiC}$ membrane at the same time that is $\mathrm{H}_{2}$ produced in the reactor, the reaction shifts to high $\mathrm{CO}$ conversion $[101,102]$. This makes the reactors smaller, which translates into lower capital costs (Capex), whilst reducing the operational costs (Opex) as water is a cheap feedstock for $\mathrm{H}_{2}$ production.

In all cases, $\mathrm{SiC}$ membranes deliver high $\mathrm{H}_{2} / \mathrm{CO}_{2}$ permselectivities (>90) [18] and could be used in the $\mathrm{H}_{2}$ production industry. The challenge here is that inevitably the feed stream operates at high temperature and pressure, and contains steam. To date studies investigating SiC membranes showed membrane failure under these harsh conditions. Hence, there is no case yet to support the deployment of $\mathrm{SiC}$ membranes as membrane reactors. The same arguments are also applied for the SiC membrane in the first set up. However, it is possible to condense the water and provide an almost dry stream for $\mathrm{H}_{2}$ separation. In this case, $\mathrm{SiC}$ membranes have to compete against traditional gas separation technologies.

An upcoming gas processing industry of interest is $\mathrm{He} / \mathrm{N}_{2}$ separation [103]. Helium stocks have reduced recently around the word and new He sources are being considered due to the importance of this noble gas in several applications. One major example is the separation of $\mathrm{He}$ from natural gas using membranes (Fig. 12). This separation can be either $\mathrm{He} / \mathrm{N}_{2}$ or $\mathrm{He} / \mathrm{CH}_{4}$. Although the concentration of $\mathrm{He}$ is low in natural gas [104], generally ranging from 0.01 to $7.0 \%$ [105], the recovery of He from these stocks is now becoming economically attractive. As $\mathrm{CH}_{4}$ concentration is likely to be very low at the back end of the natural gas processing plant, currently there is limited number of publications for $\mathrm{He} / \mathrm{N}_{2}$ permselectivity using $\mathrm{SiC}$ membranes and best results are 21 . This separation factor is moderate though superior to polymeric membranes as reported by Scholes and Ghosh [106] based on poly(trimethylsilylpropyne) ( 2), polyethylene $(\sim 7.8)$ and poly (ethylene-copropylene) (<6.5). Nevertherless, $\mathrm{He} / \mathrm{N}_{2}$ permselectivity of several polymeric membranes such as aromatic polyimide (74) [107] and inorganic membranes such as silica cobalt membrane ( 1000) [108]. These results show that $\mathrm{SiC}$ membranes require major improve- ments to separate $\mathrm{He} / \mathrm{N}_{2}$ to be competitive against other inorganic membranes.

Particle filtering using $\mathrm{SiC}$ is an established industry with two potential filtering set ups as depicted in Fig. 13a. The first set up is a conventional gas filtering process where particles are retained in the feed side of the filter, thus forming a particle cake. There are many applications such as filtering dust from air in industrial processes involving the emission of particulates. For instance, Wei et al. [32] prepared $\mathrm{SiC}$ whisker top layer coating on $\mathrm{SiC}$ supports, resulting in significant reduction of dust particles $(0.3 \mu \mathrm{m})$ concentration from 250 to $0.12 \mathrm{mg} \mathrm{m}^{3}$ and exhibiting filtration efficiency as high as $99.95 \%$. In another example, Dey et al. [27] reported that $\mathrm{SiC}$ filters delivered good performance with fractional collection efficiency of $>99 \%$ of airborne $\mathrm{NaCl}$ particles.

The second set up involves coating the filter with a catalyst. In this case, the filter allows substance $A$ to permeate whilst substance $B$ is catalytic transformed into substances $C$ and D. Upon catalytic reaction, substances C and D permeate through the filter. For instance, Sandra et al. [42] coated $\mathrm{SiC}$ filters with $\mathrm{Ce} / \mathrm{Fe} / \mathrm{Pt}$-based catalyst, which was effective in converting $\mathrm{CO}$ and hydrocarbons $\left(\mathrm{C}_{3} \mathrm{H}_{6}\right.$ and $\left.\mathrm{C}_{3} \mathrm{H}_{8}\right)$ in the presence of $\mathrm{H}_{2}$ into $\mathrm{CO}_{2}$ and $\mathrm{H}_{2} \mathrm{O}$. A second example is using honeycomb ceramic filters made of $\mathrm{SiC}$ (Fig. 13b) for dieselparticulate filters (DPFs) in the automotive industry. Diesel engines have been facing stringent regulations due to the health risk of soot emission, in addition to environmental issues associated with air quality. $\mathrm{SiC}$ filters can operate at high temperatures and are thermal shock resistance. These key properties of $\mathrm{SiC}$ filters meet the requirements to burnout the collected soot [109]. Essential to catalytic filters is the high aspect ratio (i.e., high surface area per volume). This allows honeycomb shaped filters to be excellent contactors for catalytic reactions.

\subsection{Liquid separation}

SiC filters and membranes for liquid separation is now an established industry. All the top ceramic manufacturers around the world are commercially producing $\mathrm{SiC}$ filters and membranes. In view of flexibility of processing, SiC filters and membranes are available in different shapes, pore sizes, length and diameters. Fig. 14 shows examples of commercial system such as tube assembled in a stainless steel tubular module, multi-channel flat sheets assembled in a plate-like battery module and multi-channel tubular SiC membranes. The major advantage of multi-channel arrangement in a single flat sheet or tubular membrane is the increase in the aspect ratio, as the surface area significantly increases per volume.

Owing to low temperature operation, $\mathrm{SiC}$ membranes are becoming
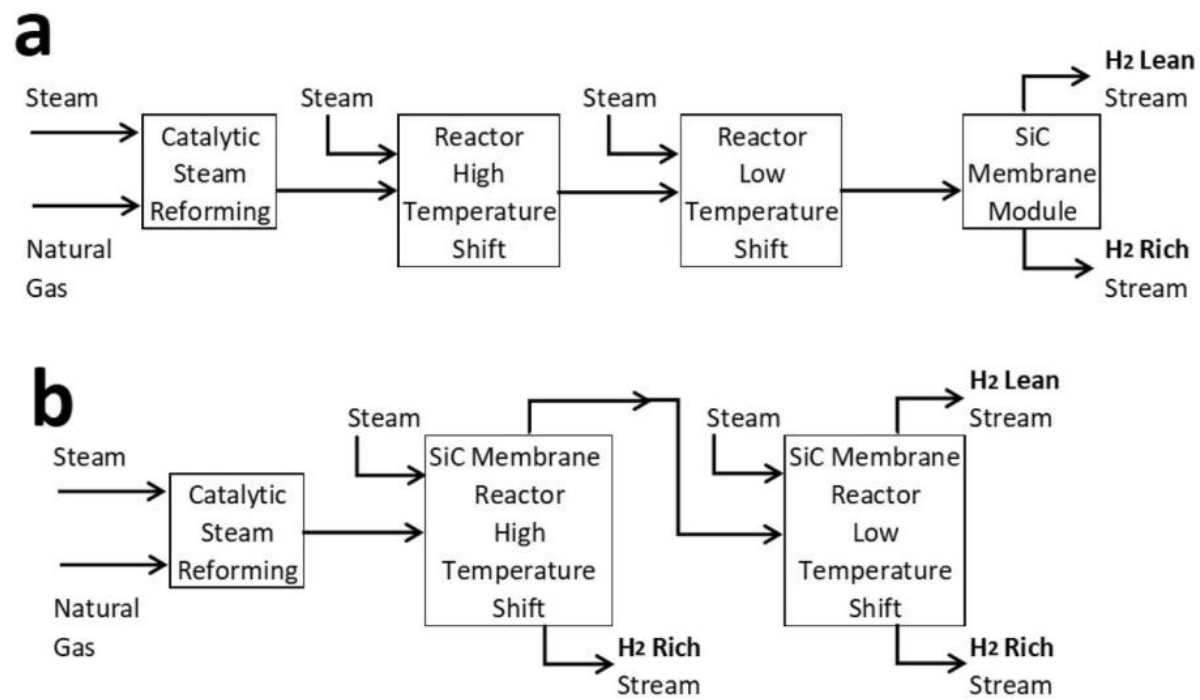

Fig. 11.Simplified block flow diagrams of natural gas steam reforming with (a) SiC membranes and (b) SiC membrane reactors. 


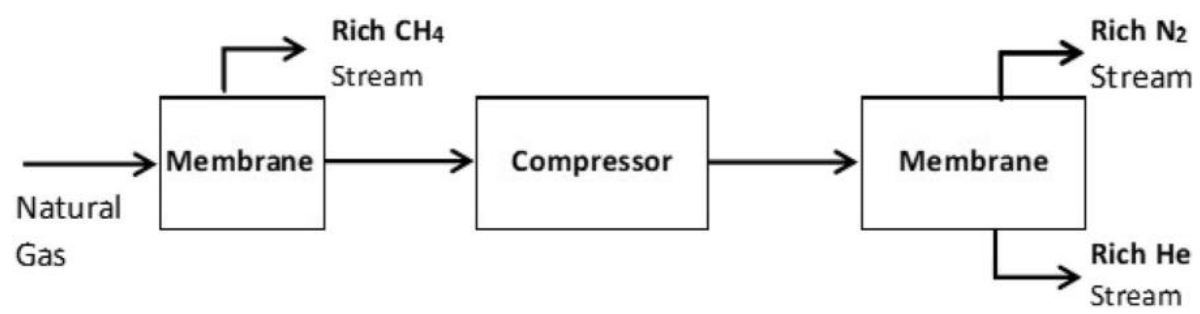

Fig. 12.Simplified block flow diagram of $\mathrm{He} / \mathrm{N}_{2}$ separation from natural gas.
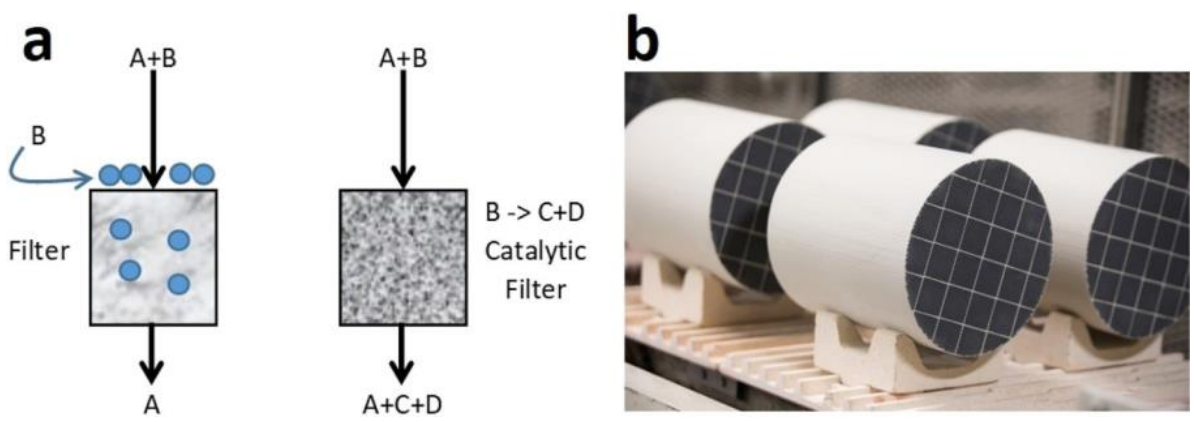

Fig. 13. (a) Simplified schematic of filters and catalytic filters, and (b) image of SiC diesel particulate filters (DPFs) [ 110]. Figs. b reprinted under copyright permission by lbiden.

a

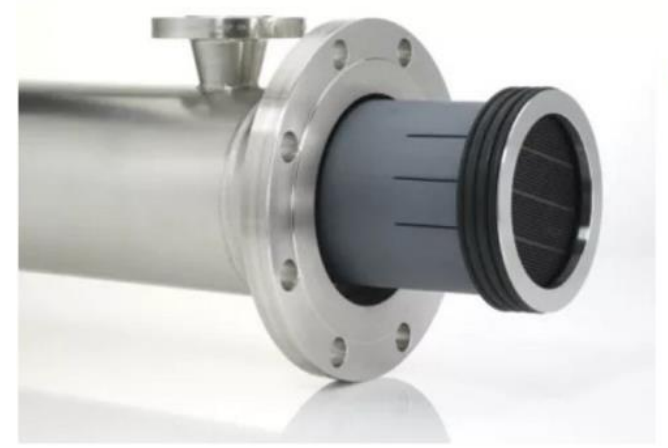

b

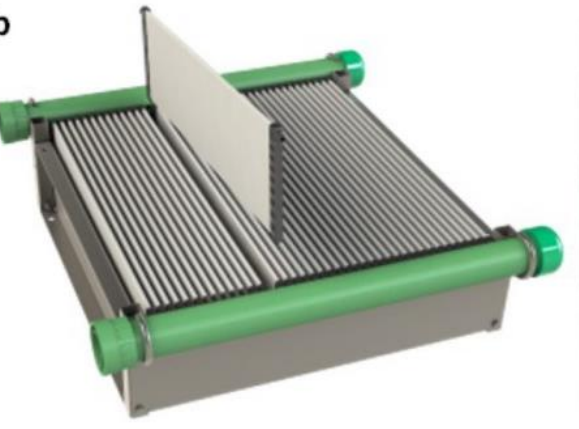

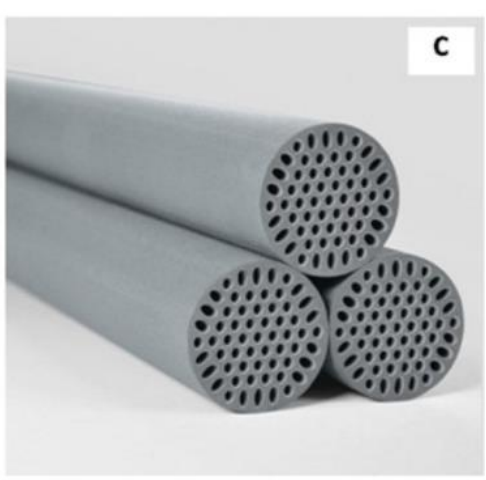

Fig. 14.SiC membranes for wastewater treatment (a) as tube assembled in a stainless steel module [ 86], (b) flat sheet membrane assembly [ 87] and (c) multi-channel tube [88]. Figs. a, b and c reprinted under copyright permission by Alsys, Cembrane and Saint-Gobain, respectively.

ideal for liquid processing, particularly in wastewater treatment plants [111]. Das et al. [37] reported that SiC membranes $\left(1.3<\mathrm{d}_{\mathrm{p}}<2.4 \mu \mathrm{m}\right)$ delivered good microfiltration efficiency by removing $89-93 \%$ of chemical oxygen demand (COD), $77-86 \%$ of oil/grease and $88.4-92 \%$ of total suspend solids (TSS). Bakishi et al. [112] employed commercial cross-flow multi-channels tubular $\mathrm{SiC}$ membranes and reported reduced total oil and grease (TOG) from 86 to $92 \mathrm{ppm}$ (feed wastewater) to 12 ppm (permeate), and fully removal of acid producing bacteria (APB).

In view of its capability of to remove oil from wastewaters, SiC membranes are finding a niche application in the food industry. For instance, SiC membranes were applied efficiently to treat wastewaters from olive oil [113] and sunflower oil [114] industries. In another example, commercial SiC membranes [88] were used for immobilization and biocatalytic efficiency improvement of enzyme (alcohol dehydrogenase) during multiple reaction cycles [115]. SiC membranes were also assembled in a bioreactor for the microfiltration of fermentation feed [116].

$\mathrm{SiC}$ membranes have also been tested by the petroleum industry which pressurizes oil reservoirs with sea water to increase oil recovery. Stringent environmental regulations require that oil companies operating sea oil platforms separate sea water from recovered oil before disposal of sea water back into the sea. This means that membrane filtration has become a viable alternative to conventional oil/water separation processes involving hydro cyclones, induced gas flotations units, micro-flotation and walnut shell filters [117]. SiC membranes are available for microfiltration and ultrafiltration, and are designed for removal of oil droplets and oil-emulsions [118], thus attractive for de-oiling water produced by oilfields.

\subsection{Gaps and challenges}

Although the body of work reported in the open literature for $\mathrm{SiC}$ filters and membranes is substantial indeed, there are several gaps that warrant further research. The most noticeable gap is the lack of studies addressing fouling of $\mathrm{SiC}$ membranes. All membranes are susceptible to fouling irrespectively of polymeric or inorganic membranes. Fouling investigations should consider long term studies $(>1000 \mathrm{~h})$ of target applications to provide some meaningful data in addition to cleaning cycles and strategies. Fouling studies could be accompanied by designing surface patterns to avoid fouling in tandem with computer fluid dynamic (CFD) modeling and validation.

The second noticeable gap is the lack of long-term investigation of 
SiC membranes. There are a few limited studies presented in the literature. However, to get the confidence of the gas/liquid separation process industry, there is a need of long-term operation as a proof-ofconcept. To some extent, the commercial availability of SiC filters and membranes is a testament that the ceramic industry has already conducted extensive long term testing on their products. Nevertheless, these applications are limited to ultra and microfiltration membranes, and high temperature gas filters. In the case of gas separation, long-term studies of SiC membranes operating under harsh conditions are warranted.

Although $\mathrm{SiC}$ filters and membranes are mechanically stable including under severe thermal shocking, their chemical stability warrants further improvement. Within a reasonable $\mathrm{pH}$ operation, $\mathrm{SiC}$ filters and membranes are stable, but at very low or very high $\mathrm{pH}$ their stability is greatly reduced. This problem can be easily addressed by dosing the $\mathrm{pH}$ in separation process. However, a more serious problem is the instability of $\mathrm{SiC}$ membranes for gas separation under harsh steam and temperature conditions. This is a problem that cannot be addressed by the industrial gas separation industry, unless lower temperatures or water condensers are used. These process solutions negate the central idea and the potential advantages of using SiC membranes for the separation of industrial humid gas streams at high pressures and temperatures.

Nevertheless, the old adage of cost is a major challenge for SiC membranes. Ceramic membranes for wastewater treatment cost in the range of $100-1000 \mathrm{USD} / \mathrm{m}^{2}$, while the price of polymeric membranes is in the range of several tens USD $/ \mathrm{m}^{2}$ [119]. Although ceramic membranes are more expensive, which influences capital cost (Capex) their development is relative recent for the last three decades as compared to polymeric membranes for the last six decades. The costs of ceramic membranes have been reducing in the last decade and the price may continue to decrease as industrial deployment increase coupled with a combination of economy of scales and improvements in manufacturing methods. Therefore, ceramic membranes have become more cost competitive and are likely to continue the downward trend in price for the same reasons as polymeric membranes did in the past. The other side of the coin in cost analysis is the process operation cost (Opex). Ceramic membranes are less fragile than polymeric membranes, have a longer and possibly indefinite life, and can withstand heavy pollutant and solid loads, vigorous backwash and a variety of chemical types and concentrations [120]. Hence, the Opex for ceramic membranes may be lower due to reduced replacement frequency, reduced mechanical/electrical engineering works and reduced shutdown costs.

\section{Conclusions and Outlook}

There is a large body of research work available in the open literature on the processing of $\mathrm{SiC}$ and $\mathrm{SiC}$ composite filters and membranes. There is a good understanding on how to control pore sizes and porosity in addition of processing a variety of shapes ranging from discs, tubes, flat sheets, honeycomb and multi-channel filters and membranes. The industrial production of $\mathrm{SiC}$ filters and membranes by major worldwide ceramic companies gives confidence of the potential uptake of $\mathrm{SiC}$ filters and membranes for industrial applications. The SiC filter industrial segment is strong particularly for high temperature gas cleaning and diesel particulate filters. Indeed the thermal stability of $\mathrm{SiC}$ is a major advantage. $\mathrm{SiC}$ membranes are making inroads into the liquid separation processes, particularly industries that required UF and MF membranes. There is an array of industrial process with potential application in wastewater, food, pharmaceutical in oil/water separation. SiC membranes are envisaged to have a great potential for gas separation. However, their chemical stability for operating at moderate to high temperatures in the presence of steam is a concern. This is the main hindrance for the deployment of $\mathrm{SiC}$ membranes due lack of reliability for operating at harsh conditions. Overall, many of the applications of $\mathrm{SiC}$ filters and porous membranes are directed to technologies to provide a better life quality, particularly in large urban areas. These include water and wastewater treatment, as well as air pollution control through catalytic reactions and/or particulate filtering. SiC faces several challenges though its ultimate goal is driven research towards environmental benign technologies.

\section{References}

[1] J. Kriegesmann, Processing of silicon carbide-based ceramics, Compr. Hard Mater. 2 (2014) 89-175.

[2] S. Chen, W. Li, X. Li, W. Yang, One-dimensional SiC nanostructures: designed growth, properties, and applications, Prog. Mater. Sci. 104 (2019) 138-214.

[3] J. Eom, Y. Kim, S. Raju, Processing and properties of macroporous silicon carbide ceramics: a review, J. Asian Ceram. Soc. 1 (2013) 220-242.

[4] N. Shcherban, Review on synthesis, structure, physical and chemical properties and functional characteristics of porous silicon carbide, J. Ind. Eng. Chem. 50 (2017) 15-28.

[5] Y. Kim, Y. Jin, J. Eom, I. Song, H. Kim, Engineering porosity in silicon carbide ceramics, J. Mater. Sci. 45 (2010) 2808-2815.

[6] C. Ferraro, E. Garcia-Tunon, S. Barg, M. Miranda, N. Ni, R. Bella, E. Saiz, SiC porous structures obtained with innovative shaping technologies, J. Eur. Ceram. Soc. 38 (2018) 823-835.

[7] S. Chae, Y. Kim, Effect of inert filler addition on microstructure and strength of porous SiC ceramics, J. Mater. Sci. 44 (2009) 1404-1406.

[8] A. Dey, O. Chakrabarti, Investigation on synthesis of cordierite bonded porous $\mathrm{SiC}$ ceramics with emphasis on bond phase formation, Mater. Chem. Phys. 222 (2019) 275-285.

[9] M. Fukushima, P. Colombo, Silicon carbide-based foams from direct blowing of polycarbosilane, J. Eur. Ceram. Soc. 32 (2012) 503-510.

[10] B. Kumar, K. Lim, Y. Kim, Influence of submicron SiC particle addition on porosity and flexural strength of porous self-bonded silicon carbide, Metals Mater. Int. 17 (2011) 435-440.

[11] K. Lim, Y. Kim, I. Song, Low-temperature processing of porous SiC ceramics, J. Mater. Sci. 48 (2013) 1973-1979.

[12] Y. Li, X. Yang, D. Liu, J. Chen, Z. Wu, Permeability of the porous $\mathrm{Al}_{2} \mathrm{O}_{3}$ ceramic with bimodal pore size distribution, Ceram. Int. 45 (2019) 5952-5957.

[13] D. Li, J. Yao, B. Liu, H. Sun, C. Feng, Preparation and characterization of surface grafting polymer of $\mathrm{ZrO}_{2}$ membrane and $\mathrm{ZrO}_{2}$ powder, App. Surf. Sci. 471 (2019) 394-402.

[14] J. Geltmeyer, H. Teixido, M. Meire, T. Van Acker, K. De Clerck, TiO 2 functionalized nanofibrous membranes for removal of organic (micro) pollutants from water, Sep. Purif. Technol. 179 (2017) 533-541.

[15] A. Ayral, A. Julbe, V. Rouessac, S. Roualdes, Microporous silica membrane: basic principles and recent advances, in: R. Mallada, M. Menêndez (Eds.), Inorganic Membranes: Synthesis, Characterization and Applications, Elsevier, Oxford, UK, 2008, pp. 33-80.

[16] V. Suwanmethanond, E. Goo, P. Liu, G. Johnston, Porous silicon carbide sintered substrates for high-temperature membranes, Ind. Eng. Chem. Res. 39 (2000) 3264-3271.

[17] R. Ciora, B. Fayyaz, P. Liu, V. Suwanmethanond, R. Mallada, M. Sahimi, T. Tsotsis, Preparation and reactive applications of nanoporous silicon carbide membranes, Chem. Eng. Sci. 59 (2004) 4957-4965.

[18] B. Elyassi, M. Sahimi, T. Tsotsis, Silicon carbide membranes for gas separation applications, J. Membr. Sci. 288 (2007) 290-297. 
[19] B. Elyassi, M. Sahimi, T. Tsotsis, A novel sacrificial interlayer-based method for the preparation of silicon carbide membranes, J. Membr. Sci. 316 (2008) 73-79.

[20] S. Ding, Y. Zeng, D. Jiang, Gas permeability behavior of mullite-bonded porous silicon carbide ceramics, J. Mater. Sci. 42 (2007) 7171-7175.

[21] M. Fukushima, Y. Zhou, H. Miyazaki, Y. Yoshizawa, K. Hirao, Y. Iwamoto, S. Yamazaki, T. Nagano, Microstructural characterization of porous silicon carbide membrane support with and without alumina additive, J. Am. Ceram. Soc. 89 (2006) 1523-1529.

[22] M. Fukushima, Y. Zhou, Y. Yoshizawa, K. Hirao, Water vapor corrosion behavior of porous silicon carbide membrane support, J. Eur. Ceram. Soc. 28 (2008) 1043-1048.

[23] M. Fukushima, Microstructural control of macroporous silicon carbide, J. Ceram Soc. Jpn. 121 (2013) 162-168.

[24] J. Eom, Y. Kim, I. Song, Effects of the initial alpha-SiC content on the microstructure, mechanical properties, and permeability of macroporous silicon carbide ceramics, J. Eur. Ceram. Soc. 32 (2012) 1283-1290.

[25] A. Dey, N. Kayal, O. Chakrabarti, M. Innocentini, W. Chacon, J. Coury, Evaluation of air permeation behavior of porous $\mathrm{SiC}$ ceramics synthesized by oxidationbonding technique, Int. J. App. Ceram. Technol. 10 (2013) 1023-1033.

[26] A. Dey, N. Kayal, O. Chakrabarti, R. Caldato, C. Andre, M. Innocentini, Permeability and nanoparticle filtration assessment of cordierite-bonded porous SiC ceramics, Ind. Eng. Chem. Res. 52 (2013) 18362-18372.

[27] A. Dey, N. Kayal, O. Chakrabarti, R. Caldato, M. Innocentini, V. Guerra Investigations on material and mechanical properties, air-permeation behavior and filtration performance of mullite-bonded porous SiC ceramics, Int. J. App. Ceram. Technol. 11 (2014) 804-816.

[28] B. Elyassi, W. Deng, M. Sahimi, T. Tsotsis, On the use of porous and nonporous fillers in the fabrication of silicon carbide membranes, Ind. Eng. Chem. Res. 52 (2013) 10269-10275

[29] K. K6nig, V. Boffa, B. Buchbjerg, A. Farsi, M. Christensen, G. Magnacca, Y. Yue, One-step deposition of ultrafiltration SiC membranes on macroporous $\mathrm{SiC}$ supports, J. Membr. Sci. 472 (2014) 232-240.

[30] F. Han, Z. Zhong, F. Zhang, W. Xing, Y. Fan, Preparation and characterization of $\mathrm{SiC}$ whisker-reinforced $\mathrm{SiC}$ porous ceramics for hot has filtration, Ind. Eng. Chem. Res. 54 (2015) 226-232.

[31] F. Han, Z. Zhong, Y. Yang, W. Wei, F. Zhang, W. Xing, Y. Fan, High gas permeability of $\mathrm{SiC}$ porous ceramics reinforced by mullite fibers, J. Eur. Ceram. Soc. 36 (2016) 3909-3917.

[32] W. Wei, W. Zhang, Q. Jiang, P. Xu, Z. Zhong, F. Zhang, W. Xing, Preparation of non-oxide SiC membrane for gas purification by spray coating. J. Membr. Sci. 540 (2017) 381-390

[33] F. Han, C. Xu, W. Wei, F. Zhang, P. Xu, Z. Zhong, W. Xing, Corrosion behaviors of porous reaction-bonded silicon carbide ceramics incorporated with $\mathrm{CaO}$, Ceram. Int. 44 (2018) 12225-12232.

[34] Y. Yang, F. Han, W. Xu, Y. Wang, Z. Zhong, W. Xing, Low-temperature sintering of porous silicon carbide ceramic support with SDBS as sintering aid, Ceram. Int. 43 (2017) 3377-3383.

[35] B. Wang, H. Zhang, H. Phuong, F. Jin, J. Yang, K. Ishizaki, Gas permeability and adsorbability of the glass-bonded porous silicon, Ceram. Int. 41 (2015) 2279 2285.

[36] S. Kim, Y. Kim, I. Song, Processing and properties of glass-bonded silicon carbide membrane supports, J. Eur. Ceram. Soc. 37 (2017) 1225-1232.

[37] D. Das, S. Baitalik, B. Haldar, R. Saha, N. Kayal, Preparation and characterization of macroporous $\mathrm{SiC}$ ceramic membrane for treatment of wastewater, J. Porous Mater. 25 (2018) 1183-1193.

[38] J. Liu, C. Tian, H. Xiao, W. Guo, P. Gao, J. Liang, Effect of B4C on co-sintering of SiC ceramic membrane, Ceram. Int. 45 (2019) 3921-3929.

[39] J. Liu, H. Xiao, W. Guo, Spheroidization of SiC powders and their improvement on the properties of SiC porous ceramics, Ceram. Int. 44 (2018) 3830-3836. Ceram. Int. 44.

[40] Y. Li, H. Wu, X. Liu, Z. Huang, Microstructures and properties of porous liquidphase-sintered SiC ceramic by hot press sintering, Materials 12 (2019) 639 , https://doi.org/10.3390/ma12040639.

[41] Y. Zhou, M. Fukushima, H. Miyazaki, Y. Yoshizawa, K. Hirao, Y. Iwamoto, K. Sato, Preparation and characterization of tubular porous silicon carbide membrane supports, J. Membr. Sci. 369 (2011) 112-118.

[42] F. Sandra, A. Ballestero, V. NGuyen, M. Tsampas, P. Vernoux, C. Balan, Y. Iwamoto, U. Demirci, P. Miele, S. Bernard, Silicon carbide-based membranes with high soot particle filtration efficiency, durability and catalytic activity for CO/HC oxidation and soot combustion, J. Membr. Sci. 501 (2016) 79-92 .

[43] S. Bukhari, J. Ha, J. Lee, I. Song, Fabrication and optimization of a clay-bonded SiC flat tubular membrane support for microfiltration applications, Ceram. Int. 43 (2017) 7736-7742.

[44] S. Bukhari, J.Ha J. Lee, L Song Oxidation-bonded SiC membrane for microfiltration, J. Eur. Ceram. Soc. 38 (2018) 1711-1719.

[45] S. Bukhari, J. Ha, J. Lee, I. Song, Effect of different heat treatments on oxidationbonded SiC membrane for water filtration, Ceram. Int. 44 (2018) 14251-14257.

[46] S. Li, C. Wei, L. Zhou, P. Wang, Z. Xie, Evaporation-condensation derived silicon carbide membrane from silicon carbide particles with different sizes, J. Eur. Ceram. Soc. 39 (2019) 1781-1787.

[47] S. Li, C. Wei, L. Zhou, P. Wang, M. Li, Z. Xie, Tuning microstructures and separation behaviors of pure silicon carbide, Ceram. Int. 45 (2019) 18788-18794.

[48] P. de Wit, E. Kappert, T. Lohaus, M. Wessling, A. Nijmeijer, N. Benes, Highly permeable and mechanically robust silicon carbide hollow fiber membranes, J. Membr. Sci. 475 (2015) 480-487.
[49] P. Lin, D. Tsai, Preparation and analysis of a silicon carbide composite membrane, J. Am. Ceram. Soc. 80 (1997) 365-372.

[50] L. Lee, D. Tsai, Synthesis and permeation properties of silicon-carbon-based inorganic membrane for gas separation, Ind. Eng. Chem. Res. 40 (2001) 612-616.

[51] T. Shimonosono, H. Imada, H. Maeda, Y. Hirata, Separation of hydrogen from carbon dioxide through porous ceramics, Materials 9 (2016) 930, https://doi. org/10.3390/ma9110930.

[52] E. Passalacqua, S. Freni, F. Barone, Alkali resistance of tape-cast SiC porous ceramic membranes, Mater. Lett. 34 (1998) 257-262.

[53] M. Fukushima, M. Nakata, Y. Zhou, T. Ohji, Y. Yoshizawa, Fabrication and properties of ultra highly porous silicon carbide by the gelation-freezing method, J. Eur. Ceram. Soc. 30 (2010) 2889-2896.

[54] H. Wu, Y. Li, X. Liu, Z. Huang, D. Jiang, Improved connectivity of gelcasted and solid-state-sintered SiC foams, J. Alloys Compounds. 712 (2017) 633-639.

[55] T. Muranaka, Y. Kikuchi, T. Yoshizawa, N. Shirakawa, J. Akimitsu, Superconductivity in carrier-doped silicon carbide, Sci. Technol. Adv. Mater. 9 (4) (2008), 044204, https://doi.org/10.1088/1468-6996/9/4/044204.

[56] S. Baklouti, J. Bouaziz, T. Chartier, J. Baumard, Binder burnout and evolution of the mechanical strength of dry-pressed ceramics containing poly(vinyl alcohol), J. Eur. Ceram. Soc. 21 (2001) 1087-1092.

[57] T. Chartier, D.B.J. Merle, Laminar ceramic composites, J. Eur. Ceram. Soc. 15 (1995) 101-107.

[58] B. Kingsbury, K. Li, A morphological study of ceramic hollow fibre membranes, J. Membr. Sci. 328 (2009) 134-140.

[59] D. Schmeda-Lopez, E. Nunes, D. Vasconcelos, W. Vasconcelos, W. Meulenberg, J. Diniz da Costa, The neck to particle ratio effect on the mechanical and morphological sintering features of porous stainless steel (SS) hollow fibers, Adv. Eng. Mater. 20 (2018) 1800045, https://doi.org/10.1002/adem.201800045.

[60] N. Tamari, T. Tanaka, K. Tanaka, I. Kondoh, M. Kawahar, M. Tokita, Effect of spark plasma sintering on densification and mechanical properties of silicon carbide, J. Ceram. Soc. Jpn. 103 (1995) 740-742, 1995.

[61] I. Kim, I. Tae, Capacity improvement of tin-deposited on carbon-coated graphite anode for rechargeable lithium ion batteries, Int. J. Electrochem. Soc. 11 (2016) 5807-5818.

[62] S. Abd-Jahil, D. Wang, C. Yacou, J. Motuzas, S. Smart, J. Diniz da Costa, Vacuumassisted tailoring of pore structures of phenolic resin derived carbon membranes, J. Membr. Sci. 525 (2017) 240-248.

[63] R. Franklin, Homogeneous and heterogeneous graphitization of carbon, Nature 77 (1956) 239.

[64] T. Konegger, R. Patidar, R. Bordia, A novel processing approach for free-standing porous non-oxide ceramic supports from polycarbosilane and polysilazane precursors, J. Eur. Ceram. Soc. 35 (2015) 2679-2683.

[65] C. Xu, C. Xu, F. Han, F. Zhang, W. Wei, Z. Zhong, Fabrication of high performance macroporous tubular silicon carbide gas by extrusion method, Ceram. Int. 44 2018) 17792-17799.

[66] W. Deng, X. Yu, M. Sahimi, T. Tsotsis, Highly permeable porous silicon carbide support tubes for the preparation of nanoporous inorganic membranes, J. Memb Sci. 451 (2014) 192-204.

[67] S. Dabir, W. Deng, M. Sahimi, T. Tsotsis, Microstructural characterization of porous silicon carbide membrane support with and without alumina additive, J. Membr. Sci. 537 (2017) 239-247.

[68] B. Bonekamp, Preparation of asymmetric ceramic membrane supports by dip coating, in: A.J. Burggraaf, L. Cot (Eds.), Fundamentals of Inorganic Membrane Science and Technology, 1996, pp. 141-226. Amsterdam, Netherlands.

[69] R. de Vos, H. Verweij, Improved performance of silica membranes for gas separation, J. Membr. Sci. 143 (1998) 37-51.

[70] J. Way, D. Roberts, Hollow fiber inorganic membranes for gas separation, Sep. Purif. Technol. 27 (1992) 29-41.

[71] L. Broens, F. Altena, C. Smolders, D. Koenhen, Asymmetric membrane structures as a result of phase separation phenomena, Desalination 32 (1980) 33-45.

[72] S. Liu, K. Li, R. Hughes, Preparation of porous aluminium oxide hollow fibre membranes by a combined phase inversion and sintering method, Ceram. Int. 29 (2003) 875-881.

[73] D. Schmeda-Lopez, S. Smart, W. Meulenberg, J. Diniz da Costa, Mixed matrix carbon stainless steel (MMCSS) hollow fibers for gas separation, Sep. Purif. Technol. 174 (2017) 150-158.

[74] M. Innocentini, P. Sepulveda, F. Ortega, Permeability, in: M. Scheffler, P. Colombo (Eds.), Cellular Ceramics: Structure, Manufacturing, Properties and Applications, Weinheim, Germany, Wiley-VCH, 2005, pp. 313-341.

[75] C. Vakifahmetoglu, D. Zeydanli, M. Innocentini, F. Ribeiro, P. Lasso, G. Soraru, Gradient-hierarchic-aligned porosity SiOC ceramics, Scientific Rep 7 (2017) 41049.

[76] M. Kanezashi, D. Fuchigami, T. Yoshioka, T. Tsuru, Control of Pd dispersion in sol-gel-derived amorphous silica membranes for hydrogen separation at high emperatures, J. Membr. Sci. 439 (2013) 78-86.

[77] A. Darmawan, J. Motuzas, S. Smart, A. Julbe, J. Diniz da Costa, Binary iron cobal oxide silica membrane for gas separation, J. Membr. Sci. 474 (2015) 32-38.

[78] B. Ballinger, J. Motuzas, S. Smart, J. Diniz da Costa, Palladium cobalt binary doping of molecular sieving silica membranes, J. Membr. Sci. 451 (2014) 185 191.

[79] S. Naserifar, T. Tsotsis, W. Goddard, M. Sahimi, Toward a process-based molecular model of SiC membranes: Prediction of transport and separation of binary gaseous mixtures, J. Membr. Sci. 473 (2015) 85-93.

[80] R. Barrer, Porous crystal membranes, J. Chem. Soc. Faraday Trans. 86 (1990) $1123-1130$. 
[81] L. Duan, Q. Ma, Z. Chen, Fabrication and CO2 capture performance of silicon carbide derived carbons from polysiloxane, Micropor. Mesopor. Mater. 203 (2015) 24-31.

[82] R. Lange, K. Keizer, A. Burggraaf, Analysis and theory of gas transport in microporous sol-gel derived ceramic membranes, J. Membr. Sci. 104 (1995) $81-100$.

[83] J. Diniz da Costa, G. Lu, V. Rudolph, Y. Lin, Novel molecular sieve silica (MSS) membranes: characterisation and permeation of single-step and two-step sol-ge membranes, J. Membr. Sci. 198 (2002) 9-21.

[84] J. Dunne, R. Mariwala, M. Rao, S. Sircar, R. Gorte, A. Myers, Heats of adsorption of polar and non-polar gases in homogeneous and heterogeneous adsorbents, in: M.D. LeVan (Ed.), Fundamentals of Adsorption, Kluwer Academic Publishers, Boston, 1996, pp. 272-284.

[85] T. Golden, S. Sircar, Gas adsorption on silicalite, J. Colloid Interface Sci. 162 (1994) 183-188.

[86] Alsys Group, Tubular modules [Online]. Available: https://www. alsys-group.com /en/ceramic-membranes/. Accessed in February 2020.

[87] Cembrane, SiC ceramic flat sheet membrane [Online]. Available: https://www. cembrane.com/sic-flat-sheet-module-ppo, 2019. Accessed in October 2019.

[88] Saint Gobain, About Crystar® filtration [Online]. Available: https://www.crysta rfiltration.saint-gobain.com/, 2019. Accessed in October 2019.

[89] S. Singhal, Thermodynamic analysis of the high-temperature stability of silicon nitride and silicon carbide, Ceram. Int. 2 (1976) 123-130.

[90] T. Narushima, T. Goto, T. Hirai, Y. Iguchi, High-temperature oxidation of silicon carbide and silicon nitride, Mat. Trans. JIM. 38 (1997) 821-835.

[91] P. Tortorelli, K. More, Effects of high water-vapor pressure on oxidation of silicon carbide at $1200^{\circledR}$ C, J. Am. Ceram. Soc. 86 (2003) 1249-1255.

[92] R. Iler, The Chemistry of Silica: Solubility, Polymerization, Colloid and Surface Properties, and Biochemistry, Wiley, New York, 1979.

[93] M. Duke, J. Diniz da Costa, D. Do, P. Gray, G. Lu, Hydrothermally robust molecular sieve silica for wet gas separation, Adv. Funct. Mat. 16 (2006) 1215-1220.

[94] L. Liu, D. Wang, D. Martens, S. Smart, J. Diniz da Costa, Influence of the cobalt phase sol-gel conditioning on the hydrothermal stability of cobalt doped silica membranes, J. Membr. Sci. 475 (2015) 425-432.

[95] R. Igi, T. Yoshioka, Y. Ikuhara, Y. Iwamoto, T. Tsuru, Characterization of codoped silica for improved hydrothermal stability and application to hydrogen separation membranes at high temperatures, J. Am. Ceram. Soc. 91 (2008) 2975-2981.

[96] M. Fukushima, Y. Zhou, Y. Yoshizawa, K. Hirao, Oxidation behavior of porous silicon carbide ceramics under water vapor below $1000^{\circ} \mathrm{C}$ and their microstructural characterization, J. Ceram. Soc. Jpn. 114 (2006) 1155-1159.

[97] M. Bugge, K. Kjaerheim, S. Føreland, W. Eduard, H. Kjuus, Lung cancer incidence among Norwegian silicon carbide industry workers: associations with particulate exposure factors, Occup, Environ. Med. 69 (2012) 527-533.

[98] DECOS, Silicon Carbide: Evaluation of the Carcinogenicity and Genotoxicity, The Health Council of the Netherlands, The Hague, 2012.

[99] S. Ding, Y. Zeng, D. Jiang, Thermal shock resistance of in situ reaction bonded porous silicon carbide ceramics, Mater. Sci. Eng. A. 425 (2006) 326-329.

[100] P. Liu, SiC-based hydrogen selective membranes for water gas-shift reaction, 31 12 2003. [Online]. Available: https://www.osti.gov/servlets/purl/829954-emlhL $\mathrm{k} /$ native/. Accessed in October 2019.

[101] S. Battersby, P. Werneck Teixeira, J. Beltramini, M. Duke, V. Rudolph, J. Diniz da Costa, An analysis of the Peclet and Damkohler numbers for dehydrogenation reactions using Molecular Sieve Silica (MSS) membrane reactors, Catal. Today 116 (2006) 12-17.

[102] S. Battersby, M. Duke, S. Liu, V. Rudolph, J. Diniz da Costa, Metal doped silica membrane reactor: operational effects of reaction and permeation for the water gas shift reaction, J. Membr. Sci. 316 (2008) 46-52.

[103] T. Rufford, K. Chan, S. Huang, E. May, A review of conventional and emerging process technologies for the recovery of helium from natural gas, Adsorpt. Sci. Technol. 32 (2014) 49-72.

[104] E. Grynia, P. Griffin, Helium in natural gas - occurrence and production, J. Nat Gas Eng. 1 (2016) 163-215, 2016.

[105] S. Hwang. R. Lein, D. Morgan, Noble gases, in: Kirk-Othmer Encyclopedia of Chemical Technology, fifth ed. ed., 2005, pp. 346-367.

[106] C. Scholes, U. Ghosh, Review of membranes for helium separation and purification, Membranes 7 (2017) 9, https://doi.org/10.3390/ membranes7010009.

[107] P. Haussinger, R. Glatthaar, W. Rhode, H. Kick, C. Benkmann, J. Weber, H. Wunschel, V. Stenke, E. Leicht, H. Stenger, Noble gases, in: Ullmann's Encyclopedia of Industrial Chemistry, Wiley-VCH, Weinheim, 2005.

[108] C. Yacou, S. Smart, J. Diniz da Costa, Long term performance of cobalt oxide silica membrane module for high temperature $\mathrm{H}_{2}$ separation, Energy Environ. Sci. 5 (2012) 5820-5832.

[109] W. Carty, P. Lednor, Monolithic ceramics and heterogeneous catalysts: honeycombs and foams, Curr. Opin. Solid State Mater. Sci. 1 (1996) 88-95.

[110] Ibiden, Diesel particulate filter [Online]. Available: https://www.ibiden.com/ product/ceramics/merchandise/dpf/, 2019. Accessed in October 2019.

[111] Z. He, Z. Lyu, Q. Gu, L. Zhang, J. Wang, Ceramic-based membranes for water and wastewater treatment, Colloid Surf. A 578 (2019) 123513, https://doi.org/ 10.1016/j.colsurfa.2019.05.074.

[112] A. Bakishi, R. Ghimire, E. Sheridan, M. Kuhn, Treatment of produced water using silicon carbide membrane filters, Ceram. Eng. Sci. Proceed. 36 (2015) 1-16.

[113] M. Fraga, S. Sanches, J. Crespo, V. Pereira, Assessment of a new silicon carbide tubular honeycomb membrane for treatment of olive mill wastewaters, Membranes 7 (2017) 12, https://doi.org/10.3390/membranes7010012.

[114] M. Fraga, S. Sanches, V. Pereira, J. Crespo, L. Yuanc, J. Marcher, M. Martínez de Yuso, E. Rodríguez-Castell@n, J. Benavente, Morphological, chemical surface and filtration characterization of anew silicon carbide membrane, J. Eur. Ceram. Soc. 37 (2017) 899-905.

[115] B. Zeuner, N. Ma, K. Berendt, A. Meyer, P. Andric, J. Hoffmann, J. Jørgensen M. Pinelo, Immobilization of alcohol dehydrogenase on ceramic silicon carbide membranes for enzymatic $\mathrm{CH} 3 \mathrm{OH}$ production, J. Chem. Technol. Biotechnol. 93 (2018) 2952-2961.

[116] Bhel, Water business profile [Online]. Available: http://www.bhel.com/index. php/pdf_view?pdf W/ater_Business_Profile.pdf, 2019. Accessed in October 2019

[117] LiqTech, Silicon carbide membrane [Online]. Available: https://www.liqtech.co $\mathrm{m} /$ silicon-carbide-membrane/, 2019. Accessed in October 2019.

[118] S. Samaeia, S. Gato-Trinidad, A. Altaeeb, The application of pressure-driven ceramic membrane technology for the treatment of industrial wastewaters - a review, Sep. Purif. Technol. 200 (2018) 198-220.

[119] S. Judd, The cost of ceramic membranes for MBRs, 27022017 [Online]. Available: https://www.thembrsite.com/blog/the-cost-of-ceramic-membrane sfor-membrane-bioreactors/. Accessed in October 2019.

[120] J. Zheng, G. Galjaard, H. Shorney-Darby [Online]. Available: https://pwnt echnologies.com/wp/wp-content/uploads/2015/04/Ceramic-microfiltration-infl uence-pretreatment-on-operational-performance-GGaljaard.pdf, 2015. Accessed in October 2019. 